UDK: 28:342.2]:321.7 Izvorni naučni rad

Prof. dr. Sulejman Topoljak, redovni profesor

Univerzitet u Bihaću

Islamski pedagoški fakultet

sulejman.topoljak@hotmail.com

\title{
NEKI ASPEKTI ISLAMSKOG POLITIČKOG SISTEMA U VIZIJI SAVREMENE DEMOKRATSKE MISLI
}

\section{Sažetak}

Tradicionalno-pravni tekstovi islama su nagovijestili da ce od islama prvo nestati (islamske) vlasti tj. političkog sistema, a zadnja stvar koju će muslimani zanemariti će biti namaz. Upravo su savremeni muslimani doživjeli taj nagovještaj, jer evo već žive bez svog vrhovnog svjetovno - vjerskog autoriteta skoro jedno cijelo stoljeće. Historija jasno potvrduje da su taj nagovještaj nemuslimani shvatili i povjerovali u njega više od samih muslimana, jer su se svim svojim potencijalima $i$ snagama dali da ga realizuju, pa su $i$ uspjeli $u$ tome, a $u$ isto vrijeme uvjerenje muslimana $u$ njega nije bilo na nivou njihova uvjerenja, pa su im dopustili da ostvare svoj najveći historijski podvig $i$ san koji im je omogućio sve ovo danas što imaju i rade. Mi duboko vjerujemo da je nestanak islamske vlasti $i$ neprimjena islamskog političkog sistema glavni uzrok svih nedaća današnjih muslimana i dok se on ne ukloni, muslimani se ne mogu nadati ničemu pozitivnom, a niti svjetlijoj budućnosti. Nakon nestanka hilafeta bilo je iskrenih $i$ stvarnih pokusaja da se ono ponovo uspostavi i reaktivira, ali nažalost oni nisu dali željene rezultate. Nakon toga je ta želja $i$ nastojanje kod muslimana polahko iščezavala $i$ na kraju su nemuslimani putem svojih satelita koje su instalirali na najeminentnijim islamskim sveucilištima uspjela da većinu muslimana $i$ njihovih kvaziučenjaka uvjeri da u islamu nema političkog sistema, a niti politike, te da vjernik može biti samo apolitičan, a nikako političan. To uvjerenje je nažalost $i$ kod nas na Balkanu preneseno što potvrduje činjenica da ni na jedinom fakultetu nemamo nijednog predmeta koji direktno ili indirektno ima veze s islamskim političkim sistemom ili islamskom politikom. Zbog tako ignorantskog odnosa ovdje kod nas prema ovako važnoj temi odlučio sam se da napišem ovu studiju čiji je cilj da ukratko i sa suvremenim jezikom istraži najvažniji element islamskog političkog sistema - instituciju vladara u islamu, 
kako bi makar malo doprinio njenoj aktualizaciji, a možda potakao $i$ podstakao nekoga da počne ozbiljno o njoj razmišljati i istraživati je, te da podsjetim sve one koji su zaboravili ili možda ne znaju da je islam cjelokupni sistem života koji involvira i principe i norme i islamskog političkog sistema, a ne samo da je religija kao i ostale poznate savremene religiji kako to mnogi naš savremeni sekularisti misle $i$ koji savjetuju svojim studentima na islamskim fakultetima kod nas da izučavaju temelje sekularizma a ne islamskog političkog sistema.

Načelno se može konstatirati da islamski politički sistem počiva na tri elementa: instituciji vladara, instituciji šure i instituciji pokoravanja vladara $i$ islamskog ummeta serijatu - islamskom ustavu $i$ zakonu. Vrijeme, prostor $i$ sam oblik studije nam ne dozvoljava da se osvrnemo i na ostala dva elementa islamskog političkog sistema.

Ključne riječi: islam, islamski politički sistem, vladar, halifa, prisega, vlast, suverenitet, narod...

\section{Uvod}

\section{Institucija vladara u islamskom političkom sistemu}

Vladar se u islamskom ustavnom pravu naziva sljedećim titulama: imam, gdje se pravi razlika između velikog kubra i malog sugra imameta. Veliki imamet aludira na vladara islamske države, a mali na predvođenje u namazu - imama, efendiju.

Isto tako, koristi se i termin halifa koji aludira na poseban politički sistem kako bi se istakla distinkcija između njega i tadašnjih uzurpatorskih političkih sistema koji su bili poznati u to vrijeme poput kajsarije i kisravije - perzijskih i bizantijskih političkih sistema koji su vladali u to doba u tim imperijama.

\section{Definicija hilafeta}

Mnogobrojni islamski pravnici su pokušali definirati hilafet i odrediti njegovu osnovnu funkciju i cilj postojanja. Čini se da je najpreciznija definicija te ustanove ona koju zastupa imamel-Maverdi, kako to navodi Ibni Haldun. Po njemu, hilafet je uspostavljen da bi zamijenio 
poslanstvo u zaštiti vjere, uređenju svijeta i zaštiti interesa primjenom njenih zakona. ${ }^{1}$

Dakle, osnovni cilj institucije vladara - halife u islamskom političkom sistemu je zamjena funkcije poslanstva, tj. zaštita vjere i ljudskih interesa te upravljanje ovim svijetom po njenim propisima i načelima.

\section{Pravna zakonitost institucije vladara - hilafeta u islamskom političkom sistemu}

Po mišljenju većine islamskih pravnika izbor i ustoličenje vladara halife u islamu je kolektivna vjerska dužnost - fardul-kifaje. Dakle, svi muslimani su obavezni sukladno svojim sposobnostima i mogućnostima za njenu realizaciju i ukoliko se ona ne izvrši cijeli ummet snosi grijeh i posljedice koje proističu od zanemarivanja tog vadžiba. Postoji i drugo mišljenje koje zastupa neznatan broj učenjaka i po kom ustoličenje vladara u islamu nije vjerska obaveza, već nešto što je dozvoljeno - džaiz po potrebi.

Međutim, ono je raritet.

Nužnost postojanja institucije vladara u islamskom političkom sistemu se može dokazati s mnogobrojnim dokazima iz različitih islamskih izvora. Navest ćemo neke od njih:

1. O vjernici, pokoravajte se Allahu i pokoravajte se Poslaniku $i$ predstavnicima vašim. (En-Nisa, 59.)

Ajet naređuje muslimanima da se pokore svojim predstavnicima, a da bi im se mogli pokoriti neophodno ih je imati na vlasti. Pod predstavnicima se po nekima misli na vladare, a po nekima i na vladare i na učenjake - ulemu.

2. Poslanik, a.s., je rekao: „Ko umre, a ne bude o vratu imao prisegu, umrijet će jednom vrstom idolopokloničke smrti.“ (Muslim)

„Islama će nestajati sve dio po dio. Prvo što će od njega nestati je vlast, a posljednje namaz».(Ibn Madže, Ahmed i Hakim)

„Kada trojica krenu na put neka izaberu sebi vođu.“ (Ebu Davud)

${ }^{1}$ Maverdi, El-Ahkamus-sultanijje, str. 5., Ibn Haldun, El-Mukaddime, 145. 
3. Konsenzus. Ashabi su poslije smrti Poslanika, a.s., bili potpuno saglasni da je neophodno uspostaviti spomenutu instituciju, pa su izabrali Ebu Bekra, r.a., kao prvog halifu.

el-Maverdi je rekao: „Uspostava halife koji će izvršavati dužnost hilafeta je vadžib koji je potvrđen konsenzusom. “2 Ibn Haldun je rekao: „Postavljanje halife je vadžib koji se temelji u šerijatu na konsenzusu ashaba $\mathrm{i}$ tabiina..." 3

4. Sama priroda islamsko-pravnih normi i propisa zahtijeva postojanje halife, jer se većina njih ne može primijeniti bez postojanja islamske vlasti poput džihada, krivičnog prava, uspostava pravde, itd.

U tom značenju, Gazali je još bi decidniji kada je rekao: ,Vjera i vlast su blizanci. Vjera je temelj, a vlast čuvar. Ono što nema temelja rušljivo je, a ono što nema čuvara nezaštićeno je. ${ }^{\text {“4 }}$

Gazali, dakle, eksplicite tvrdi i zastupa stav da se islam ne može u potpunosti primijeniti bez ovosvjetske vlasti, a niti se ovaj svijet može normalno i pravedno urediti i voditi bez islama što ukazuje na njihovu usku vezu koja se ne smije nikada kidati, jer to kidanje znači fesad nered u cijelom kosmosu.

\section{Institucija hilafeta kod šija}

Šije instituciju vladara - hilafet nazivaju sa terminom imamet- liderstvo. Po mišljenju njihovih učenjaka, uspostava institucije imameta ne samo da je vjerska obaveza - vadžib, nego i osnovni temelj vjere - rukn. S tim što pravo na njenu uspostavu ne pripada narodu - ummetu, nego Allahu.

Oni smatraju da je vjerovanje u postojanje imameta temeljna stvar vjere bez koje se ne može upotpuniti iman - vjerovanje. Dakle, kod njih je vjerovanje $\mathrm{u}$ imamet temelj vjere i jedini put preko koga se mogu spoznati ostali njeni temelji. Na osnovu toga, temelji imana kod šija su: vjerovanje u: Boga, meleke, kitabe, poslanike, Sudnji dan, određenje -

\footnotetext{
${ }^{2}$ Maverdi, El-Ahkamus-sultanijje, str. 3., Ibn Haldun, El-Mukaddime, 191.

${ }^{3}$ Ibn Haldun, El-Mukaddime, 191.

${ }^{4}$ Gazali, El-Iktisadu fil-'itikadi, str. 135.
} 
sudbinu i njihove imame. Prema tome, ko ne vjeruje u imamet, po njima, nije vjernik.

Iz navedenog se da zaključiti da većina islamskih učenjaka smatra uspostavu hilafeta - obligatnom vjerskom dužnošću - vadžib, pa čak i najvažnijom vjerskom obavezom od koje zavisi primjena i realizacija ostalih islamskih dužnosti i obaveza. U tom smislu imam Džurdžani je rekao: „Uspostava institucije hilafeta je najveći interes muslimana, kao i najveća vjerska intencija - cilj. “5

\section{Uvjeti koji se uslovljavaju za obnašanje instituciju hilafeta}

Islamski pravnici uslovljavaju određene uvjete koji se moraju naći kod onoga koji se bira za vladara islamske države. Neki od njih su plod idžtihada, a drugi su preuzeti direktno iz pravnih tekstova koji tretiraju tu tematiku. Cilj njihova uslovljavanja je da se omogući osobi koja se izabere na taj položaj realizacija osnovne intencije institucije hilafeta, te da se prevenira izbor onih koji nisu kompetentni da to izvrše.

Imam el-Maverdi smatra da se kod onoga koji se bira za funkciju vladara u islamu moraju naći sljedeći uvjeti:

1. adalet, tj. pobožnost i moralnost,

2. znanje, tj. da bude mudžtehid ili kompetentan za tu funkciju,

3. tjelesna i umna sposobnost i zdravlje,

4. nadarenost i stručnost,

5. hrabrost i autoritativnost,

6. porijeklo, tj. autoritativnost,

7. islam $\mathrm{i}$

8. muški spol.

\section{Porijeklo kao uvjet da se bude halifa}

Od navedenih uvjeta, jedino postoje dileme kod učenjaka oko porijekla, jer se u pravnim tekstovima uslovljava da halifa mora biti iz plamena

${ }^{5}$ Džurdžani, Šerhul-Mevakif, 8/347. 
Kurejš. Dileme su upravo nastalo oko toga da li je taj uvjet doktrinarne ili pravne prirode.

Većina islamskih učenjaka uslovljavaju da halifa treba biti Kurejšević. Svoj stav temelje na vjerodostojnim hadisima koji to tretiraju poput: „Vladari trebaju biti od Kurejševića.“ „Liderstvo će pripadati Kurejševićima sve dok na Zemlji ostanu makar i dva čovjeka.“ (Buharija)

Spomenuti hadisi eksplicite uslovljavaju kurejševičko porijeklo za izbor halife. Međutim, postavlja se pitanje, koja se mudrost krije od njegova uslovljavanja? Da li se on uslovljava zbog odlikovanosti i superiornosti tog plemena, te njegova berićeta zbog toga što Poslanik, a.s., vodi porijeklo iz njega, ili zbog neke druge mudrosti?

Prvu konstataciju ne možemo prihvatiti, jer se ona suprotstavlja osnovnoj intenciji islama da su svi ljudi jednaki i da se ne smiju diskriminirati na osnovu porijekla, jezika, boje kože, itd. Prema tome, ostala je druga mogućnost, tj. da se taj uvjet uslovljava zbog nečeg drugog.

Od islamskih učenjaka, koliko nam je poznato, navedene hadise u tom drugom značenju kako smo gore ukazali, jedino je razumio Ibn Haldun. U tom smislu je rekao: „Mi ako budemo tražili mudrost $\mathrm{i}$ intenciju tog uvjeta, tj. kurejševičkog porijekla kojeg Zakonodavac uslovljava, zapazit ćemo da se on ne uslovljava samo zbog blagoslova Poslanikove porodice, kako se to na prvi pogled čini i prihvata. Ako ga studiozno promotrimo, zapazit ćemo da se on uslovljava ne zbog toga, nego zbog autoritativnosti, moći i ugleda kojeg su uživali Kurejševići u to vrijeme, tj. radi osobina koje su bili presudne vladarima tog vremena da budu uspješni, prihvaćeni i da im se narod pokori. Zato mi smatramo da onaj koji se u svako vrijeme bude birao za halifu ili lidera, mora da bude autoritativan, priznat i uvažavan u narodu. “6

Međutim, važnost porijekla danas u savremenom političkom sistemu i politici je izblijedjelo i postalo nebitno, ali se poimanje tog uvjeta po Ibn Haldunovoj teoriji može i pored toga $\mathrm{i}$ danas primijeniti, i to na način da se izabere onaj kandidat za halifu kojeg narod najviše uvažava i cijeni. Nema nikakve šerijatske zapreke da se ta osobina sazna i otkrije

${ }^{6}$ Ibn Haldun, El-Mukaddima, str. 262. 
putem glasanja, nakon čega bi sukladno rezultatima tog glasanja predsjednik islamske države postao onaj kandidat za kojeg glasa većina muslimanske glasačke populacije.

$\mathrm{Na}$ osnovu toga, nema nikakve zakonske prepreke da se ovaj uvjet zamijeni i primijeni na drugi način, a da njegova intencija ostane ista, tj. da se on primijeni nad onim predsjedničkim kandidatom koji dobije najviše ili većinu glasova islamskog biračkog tijela i da na osnovu toga postane predsjednik islamske države. Prema tome, najveći zastupnici savremene demokracije nisu u svojim teorijama donijeli ništa novo $u$ odnosu na ovu Ibn Haldunovu teoriju.

\section{Način izbora vladara - halife $u$ islamskom političkom sistemu}

Islamski učenjaci po ovom pitanju su, može se reći, saglasni da se izbor vrši po određenim procedurama i načinima od kojih se ne smije odstupiti.

Prije svega, islamski politički sistem je definirao prisegu - el-bej'akao način za inauguraciju vladara $u$ islamskoj državi koja se vrši u ime cijelog ummeta.

Prisega - bej'a se definira kao dobrovoljni i izborni ugovor između naroda i vladara koji nakon sklapanja obavezuje obje strane; vladara da vodi ummet sukladno Kur'anu i sunnetu, te da izvršava ostale svoje dužnosti, a ummet da mu se pokori i potpomogne ga sve dok bude izvršavao svoje spomenute dužnosti i obaveze sukladno ustavu Kur'anu.

\section{Dokazi legitimnosti prisege $\mathbf{u}$ islamskom političkom sistemu}

Prisega je u Kur'anu spomenuta na mnogim mjestima, kao npr.: Oni koji su ti se zakleli na vjernost zakleli su se doista na vjernost samom Allahu, Allahova ruka je iznad njihovih ruku. Onaj ko prekrši zakletvu krši je na svoju štetu, a ko ispuni ono što se obavezao Allahu, On će mu dati veliku nagradu. (El-Feth, 10., El-Mumtehane, 13., El-Feth, 18.) 
Ona se spominje i u mnogobrojnim hadisima poput: „Ko dadne prisegu nekom vođi i dadne mu svoju ruku i pristanak neka mu se pokori ako je u mogućnosti!‘7

„Ko umre a ne bude pod prisegom umrijet će jednom vrstom džahilijetske smrti." ${ }^{\circ}$

„Poslije mene nema poslanika, ali će biti mnoge halife. Ashabi su upitali: „Šta nam naređuješ Allahov Poslaniče?“ Rekao je: „Izvršavajte po redu date prisege.“ (Buharija i Muslim.)

Navedeni pravni tekstovi su eksplicitni u tome da je prisega obavezan ugovor koji se mora izvršiti.

\section{Pitanje zastupništva u prisežnom ugovoru - el-bej'u}

Institucija zastupništva u izvršenju građanskih i drugih obaveza je poznata i legalna u islamskom pravu. S toga, islamski pravnici ustavnog prava dozvoljavaju da zastupničko vijeće - ehlul-halli vel-'akdi kojeg izaberu muslimani ima pravo i može ih zastupati u prisežnom ugovoru koji se zaključuje između muslimana - ummeta i islamskog vladara halife.

Dokaz na kojem se temelji spomenuti stav je prisežni ugovor koji se zaključio kod mjesta zvanog Ridvan na kom je Poslanik dao prisegu za Osmana, r.a. ${ }^{9}$

\section{Pravo islamskog ummeta pri izboru vladara islamske države}

$\mathrm{U}$ islamskom političkom sistemu islamskom ummetu pripada pravo izbora lidera islamske države - halife.

To potvrđuju eksplicitni citati najeminentnijih islamskih učenjaka.

\footnotetext{
${ }^{7}$ Ibn Hazm, El-Muhalla, 9/439.

${ }^{8}$ Ibid. $9 / 438$.

${ }^{9}$ Ibn Kesir, Tefsirul-Kur'anil-'azim, 4/186.
} 
Bagdadi je npr. o tome rekao: „Većina naših sljedbenika smatra misleći na ehlis-sunnet vel -džema'a, mutezile, haridžije i dr., da se izbor halife legalizuje njegovim izborom od strane ummeta." ${ }^{10}$

Spomenuti stav potvrđuje i Ibn Haldun koji nedvosmisleno tvrdi da to pravo pripada ummetu u kontekstu njegova govora o utemeljenosti institucije halife $\mathrm{u}$ islamskom pravu gdje navodi da ta institucija ima status kolektivne obaveze - fard-kifaje i da se realizuje putem zastupničkog ili izbornog vijeća - ehlul- ihtijar kako ga je nazvao Maverdi. ${ }^{11}$

Gazali je o tome rekao: „Ako se odmah u startu izbora halife uslovljava autoritativnost i moć...onda je logično da se to ne može realizovati bez većine koja je nužna u svakom vremenu. “12

Ibn Tejmijje je rekao: „...Nema sumnje u to da se za legalnost kod izbora halife uslovljava konsenzus izbornog tijela i pri tome se u obzir ne uzima protivljenje nekolicine; jednog ili dvojice, jer ako bi se na to gledalo, onda se nikada ne bi realizirala institucija hilafeta. “13

Iz citiranih mišljenja spomenutih učenjaka se jasno vidi da oni nedvosmisleno potvrđuju da pravo izbora halife pripada samo islamskom ummetu i da bez njegova slobodna i dobrovoljna izbora niko, ma ko on bio, ne može biti inauguriran u lidera islamske države.Također se iz spomenutih citata razumije i da je ummet druga strana prisežnog ugovora jer je poznato da se ugovor ne može uspostaviti na osnovu samo jedne ugovorne strane.

\section{Osnova na kojoj se temelji pravo islamskog ummeta za izbor halife ili njegovo pravo na prisežni ugovor}

Pravo muslimana na izbor halife ili njegovo pravo na prisežni ugovor se temelji na nekoliko činjenica od kojih su:

Prvo - što je islamski ummet odgovoran za primjenu i realizaciju šerijata. Kur'an se kod propisivanja propisa direktno obraća islamskom

\footnotetext{
${ }^{10}$ Bagdadi, Usulud-din, str. 279.

${ }^{11}$ Ibn Haldun, El-Mukaddima, str. 193.

12 Ibid.

${ }^{13}$ Ibn Tejmijje, El-Munteka min minhadžil-i'tidal, str. 546.
} 
ummetu i naređuje mu da ih primjeni. To se jasno može primijetiti kod propisivanja normi građanskog, krivičnog i drugih oblasti prava i u isto vrijeme smatra odgovornim islamski ummet za njihovu neprimjenu.

Kao primjer mogu se navesti slijedeći ajeti:

A vjernici i vjernice su prijatelji jedni drugima: traže da se čine dobra djela, a odvraćaju od nevaljalih... (Et-Tevba, 71.)

O vjernici, budite uvijek pravedni, svjedočite Allaha radi, pa i na svoju štetu ili na štetu roditelja i rođaka...(En-Nisa, 135.)

Kradljivcu i kradljivci odsijecite ruke...(El-Maide, 38.)

Bludnicu i bludnika izbičujte po sto bičeva...(En-Nur, 2.)

Svi spomenuti i mnogi još drugi slični tekstovi jasno se obraćaju ummetu i čine ga odgovornim za primjenu šerijata. Ako je islamski ummet na osnovu spomenutih i drugih sličnih

Kur'anskih tekstova odgovoran za realizaciju islamskog vjerozakona, onda je logično da ummet posjeduje i pravo na vlast na to koje mu je dao sam Zakonodavac. Međutim, pošto je praktično nemoguće da cijeli ummet upražnjava sve ovlasti koje mu pripadaju i koje mu omogućuju da izvrši tu svoju obavezu, onda mu se nužno nameće u tome institucija zastupništva. Na taj način se javilo u islamskom ummetu zastupništvo kod izbora imama ili islamskog lidera koji će umjesto njega - ummeta izvršavati sve njegove obaveze kojim ga je zadužio Zakonodavac nakon što mu ummet da ovlasti i prava na to.

To nimalo nije nepoznato islamskom pravu, jer ono ne obavezuje onoga koji posjeduje neke ovlasti ili prava da ih mora lično konzumirati i upražnjavati, nego mu se dozvoljava da nađe zastupnika koji će ih u ime njega obavljati.

Drugo - što mnogobrojni hadisi koji obavezuju islamski ummet da izabere $\mathrm{i}$ inaugurira sebi lidera $\mathrm{i}$ koji $\mathrm{u}$ isto vrijeme zabranjuju mu da bude bez lidera.

Treće - što to sama Poslanikova praksa potvrđuje, jer se zna da je Poslanik, a.s., umro a da nije odredio sebi zamjenika. To nije učinio, kako tvrde neki orijentalisti, zbog toga što ga je smrt iznenadila, ili što nije htio da prekrši arapsku tradiciju kod izbora plemenskog lidera, što se ni u kojem slučaju ne može prihvatiti, nego je to isključivo uradio 
Želeći na taj način tim svojim postupkom implicite poručiti ummetu da to pravo pripada ekskluzivno samo njemu i nikome drugom.

$\mathrm{Na}$ to aludira i Prva i Druga Akaba koja je bila istinski ugovor između Poslanika s jedne strane i ensarija s druge strane s ciljem zajedničkog osnivanja i uspostave islamske države čija se realizacija i desila nakon Hidžre.

Četvrto - što je konsenzus ashaba uspostavljen oko toga da pravo izbora islamskog lidera pripada islamskom ummetu, jer nije potvrđeno pravnim tekstom. Taj konsenzus je potvrđen u mnogim ustavnim sjednicama i sesijama koje su se desile odmah poslije smrti Poslanika, a.s., i nije poznato da se iko od ashaba usprotivio tomu.

\section{Neposredno i posredno biranje islamskog lidera - halife}

Ako pravo izbora halife pripada islamskom ummetu,onda se postavlja pitanje na koji način će ummet primijeniti u stvarnosti to svoje pravo $\mathrm{i}$ izabrati halifu?

Da li direktnim glasanjem od strane svakog pojedinca $\mathrm{u}$ islamskom ummetu ili neposredno putem izbornog vijeća kojeg će izabrati i povjeriti mu tu obavezu?

$\mathrm{U}$ islamskom političkom sistemu i ustavu mi nemamo nikakvih naznaka da se jedan metod preferira nad drugim, ili da je jedan zabranjen a drugi dozvoljen, što znači da je ta stvar prepuštena ummetu da se on treba odrediti prema jednom od spomenute metode izbora sukladno okolnostima i vremenu u kojem se ta obaveza realizuje. Prema tome, islamsko političko pravo i opća islamska pravila su dovoljno opširna da prihvate i uvaže oba načina izbora islamskog vrhovnog lidera.

Direktno biranje halife u islamu od strane svakog građanina islamske države se može opravdati i dokazima. Tako se npr. u slijedećem ajetu veli:...i koji se u poslovima svojim dogovaraju. (Eš-Šura, 38.)

Spomenuti ajet eksplicite zahtijeva da se članovi islamskog ummeta trebaju dogovarati u svojim poslovima i stvarima u što spada i jedna od najvećih i najvažnijih obaveza-izbor halife. Zato su svi njegovi članovi dužni upražnjavati to pravo osim onih kojima je ono iz opravdanih razloga uskraćeno. 
Ovakvo poimanje potvrđuje i mišljenje imama Razija o kojem se izjasnio prilikom tumačenja spomenutog ajeta. On veli: „Kada im iskrsne neki problem, oni se sastanu i međusobno se dogovore i ne rade to na drugi način. A ako se ne usaglase po nekom pitanju, oni ga i ne prihvataju." 14

Što se tiče metode indirektnog izbora halife, njena utemeljenost se može opravdati ustavnim postupcima koji su se dešavali za vrijeme četverice pravednih halifa u tom zlatnom periodu islamske historije. U njemu su halife birane posredno putem izbornog vijeća. Oni su prvi birali halifu, a potom su se za njima povodili i ostali muslimani koji su bili u Medini i davali mu prisegu. Prema tome, u njegovom izboru nisu učestvovali svi muslimani iz svih islamskih krajeva. Nije zabilježeno niti zapamćeno da se iko usprotivio ovakvom načinu izbora ni od samih halifa, niti od ostalih ashaba, što znači da je on prihvaćen konsenzusom ashaba. $^{15}$

Posredni način izbora halife bi se mogao opravdati i logičnim dokazima, na način što pravo izbora halife pripada islamskom ummetu i zato on ima pravo da izabere grupu ljudi koji će to pravo izvršiti umjesto njega jer se ne uslovljava onome koji posjeduje neke ovlasti i prava da ih lično mora i realizovati. Islamski pravnici su se jasno izjasnili da je izbor halife na posredan način dozvoljen kada su rekli da imama bira izborno vijeće - ehlul-halli vel-'akdi.

\section{Opća i posebna prisega}

Iz izloženog se da zaključiti da se izbor halife vrši od strane izbornog tijela koje se u islamsko- ustavnopravnoj literaturi naziva različitim imenima poput: ehlul-ihtijar, ehlul-idžtihad, ehluš- šura, ehluš-ševke a koje je izabrano od strane islamskog ummeta s ciljem da izvrši umjesto njega njegovu najveću obavezu - izbor halife putem posebne prisege. $\mathrm{Na}$ tu vrstu prisege aludiraju islamski učenjaci kad govore o tome ko treba da izabere halifu. Tako npr. el-Maverdi je rekao: „Izbor halife se

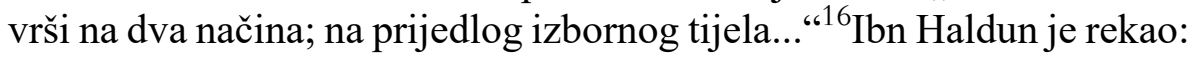

\footnotetext{
${ }^{14}$ Razi, Mefatihul-gajb, 27/177.

${ }^{15}$ Vidi: Abdulkerim Zejdan, El-Ferdu ved-devletu fiš-šeri'atil-islamijje, str. 18.

${ }^{16}$ Maverdi, El-Ahkamus-sultanijje, str. 6.
} 
„Izbor halife je kolektivna obaveza muslimana, a vrši ga savjetodavno vijeće.“17

Ova vrsta prisege o kojoj govore islamski učenjaci, mogla bi se danas u savremenoj demokratiji donekle poistovjetiti sa posrednim izborom gdje predstavnici naroda - parlamentarci biraju predsjednika države.

A pod općom prisegom se misli na prisegu po kojoj svi muslimani koji se nađu u glavnom gradu islamske države daju prisegu halifi u gradskoj džamiji ili gdje nakon posebne prisege svi muslimani u svim krajevima islamske države daju prisegu halifi.

Ta prisega odgovara onom što se danas naziva sveopći narodni plebiscit ili neposredni izbor. Oba spomenuta načina su šerijatski legalna i po kojem god od njih se izabere halifa njegov izbor će biti validan.

Međutim, bitno je istaći ovdje da su se većinom kod izbora halife koristila oba metoda kako bi se na taj način istakla važnost prisege i skrenula pažnja na prava i dužnosti obje strane, $\mathrm{tj}$. islamskog ummeta i halife koje proističu iz tog ugovora.

\section{Institucija prestolonasljednika i pravo islamskog ummeta u njoj}

Pod spomenutim naslovom mislimo na situaciju kada vladar oporuči nekoga ko će ga naslijediti na tom položaju, sina ili nekog drugog. Historija islama je zapamtila ovakav način izbora halife. Npr. Ebu Bekr, r.a., je oporučio da ga naslijedi Omer, r.a.

Postavlja se pitanje da li su takvi postupci dozvoljeni u islamu, tj. da li su oni oprečni općem ustavnom islamskom pravilu koje nalaže da ekskluzivno pravo na izbor halife ima samo islamski ummet i niko drugi?

Analizirajući mišljenja islamskih pravnika o spomenutom pitanju da se zaključiti da predmetno oporučivanje načelno ne izlazi iz okvira tog pravila ukoliko islamski ummet prihvati oporučenog kandidata. Dakle, ukoliko islamski ummet nekoga prihvati za halifu postat će halifom, a ako ne, njegovo predlaganje je nevalidno i nema nikakav značaj.

${ }^{17}$ Ibn Haldun, El-Mukaddime, str. 193. 
To potvrđuju sljedeći citati meritornih islamskih učenjaka. El-Maverdi je rekao: „Dozvoljeno je nekom vladaru da imenuje svog nasljednika...jer to njegovo imenovanje se ne smatra i konačnom inauguracijom predloženog, jer on ne postaje halifa na osnovu samog tog prijedloga, nego njegovim prihvatanjem i pristankom islamskog ummeta."18

Prema tome, sve dok se izborno vijeće javno ne očituje da prihvata predloženog za halifu muslimana, on se ne smatra, niti se može prihvatiti za islamskog lidera. To je jasno zapazio imam Ibn Tejmijje kada je rekao: „Omer kada ga je Ebu Bekr predložio za svog nasljednika, postao je halifom tek onda kada su mu muslimani dali prisegu i prihvatili ga za halifu. Međutim, da se kojim slučajem desilo da su muslimani odbili izvršiti Ebu Bekrovu oporuku i da mu nisu dali prisegu Omer ne bi, samo na osnovu te oporuke, mogao postati halifa." 19

Nasljeđivanje vlasti islam ne priznaje $\mathrm{i}$ to je potvrđeno konsenzusom. Ibn Haldun o tome je rekao: „Ako se putem institucije prestolonasljednika želi sačuvati položaj svojim sinovima, onda je to suprotno šerijatskim intencijama, jer je vlast Allahova stvar, daje je kome hoće od Svojih robova. S toga je nužno onome ko je napušta da koliko god je to moguće očisti svoj nijjet iz bojazni da se ne bi desilo poigravanje sa vjerskim funkcijama. ${ }^{\text {‘20 }}$

Ibn Hazm je po tom pitanju bio još jasniji kad je rekao: „Nema dileme ni kod jednog islamskog učenjaka o zabrani nasljeđivanja vlasti.“21

\section{Priroda i suština prisežnog ugovora - el-bej'a}

Prisežni ugovor - el-bej'a je po svojoj prirodi i biti izborno-obvezujući za obje strane. Da je to izborni ugovor potvrđuju mnogobrojne izreke islamskih pravnika pri njihovu opisu forme koju treba izreći kada se spomenuti ugovor sklapa. Oni smatraju da se ta forma treba izreći na

\footnotetext{
${ }^{18}$ Maverdi, El-Ahkamus-sultanijje, str. 4., Ebu J'ala, El-Ahkamus-sultanijje, str. 7.

${ }^{19}$ Ibn Tejmijje, Minhadžus-sunneh, 1/141.142., Gazali, Er-Reddu 'alel-batinijje, str. 66.

${ }^{20}$ Ibn Haldun, El-Mukaddime, str. 176.

${ }^{21}$ Ibn Hazm, El-Faslu fil-mileli ven-niheli, 4/167.
} 
sljedeći način od strane onih koji daju prisegu: Dajemo ti dobrovoljno prisegu za uspostavu pravde, pravičnosti i izvršavanje svih obaveza koje nalaže funkcija koju preuzimaš. ${ }^{22}$

A da je taj ugovor i obavezan za obje strane, potvrđuje činjenica što je halifa dužan uspostaviti pravdu, pravičnost i sve obaveze koje ta funkcija nalaže. To se može postići samo ako se bude vladalo po zakonu Kur'ana, sunneta i pravilnom donošenju rješenja na osnovu šerijatskih pravila pri vršenju te funkcije koja se ogleda u zaštiti vjere i upravljanju, sukladno njenim normama, pitanjima ovoga svijeta. Sve se to može nazvati jednim imenom - primjenom šerijata, jer se sklopljeni ugovor upravo i odnosio na taj predmet, $\mathrm{tj}$. te obaveze.

Spomenuti ugovor je također, obavezan i za islamski ummet. On ga obavezuje na pokornost, dosljednost, pružanje savjeta, međusobnog dogovaranja, te zabrane dizanje pobune protiv halife bez opravdana razloga, jer se pobuna protiv vladara u islamu smatra nasiljem bagjom, a bagj je nelegalna pobuna protiv legalno izabranog vladara El-bagju huvel-hurudžu 'alel-imamil-hakki bigajril-hakki.

Kur'an i sunnet pozivaju da se spomenuti ugovor izvrši i da se ne krši od strane ummeta, jer je to obavezni ugovor a Allah je rekao za ugovore: O vjernici, ispunjavajte obaveze! (El-Maide, 1.) Taj ugovor Ibn Haldun naziva i ugovorom obavezivanja na pokornost. ${ }^{23}$

I ispunjavajte obavezu, jer će se za obavezu, zaista, odgovarati. (ElIsra, 34.)

Ne samo to, nego islam smatra onog ko ne ispunjava preuzete obaveze da izlazi iz imana. Poslanik, s.a.v.s., je rekao: „Nema imana onaj u koga se nema povjerenja, a nema vjere onaj ko obaveze ne ispunjava.“ (Ahmed)

El-Maverdi objašnjavajući obaveze ummeta prema vladaru koji izvršava svoje obaveze je rekao: „Kada vladar izvrši obaveze prema ummetu on je na taj način izvršio Allahovo pravo, tj. obaveze prema Njemu. Muslimani su tada obavezni prema njemu dvije stvari: da mu

\footnotetext{
${ }^{22}$ Ebu J'ala, El-Ahkamus-sultanijje, str. 9.

${ }^{23}$ Ibn Haldun, El-Mukaddime, str. 209.
} 
se pokore i da ga savjetuju ukoliko mu treba savjet, tj. ukažu na propuste da se popravi.“24

\section{Položaj halife u ustavnopravnom sistemu islama}

Ovdje se želi pojasniti status položaja kojeg obnaša halifa ili vladar i njegov odnos prema podređenima,te priroda $\mathrm{i}$ bit tog prava pri obnašanju te funkcije.

Većina islamskih pravnika smatra da je položaj kojeg obnaša halifa zastupnički ili predstavnički, jer u biti halifa samo zamjenjuje ili zastupa islamski ummet u pravima koja mu je ummet povjerio da bi umjesto njega mogao izvršiti njegovu najveću obavezu predstavljenu u primjeni Allahova zakona - šerijata.

Ko požljivo prouči mišljenja islamskih pravnika po ovom pitanju zapazit će da oni ovdje proklamuju jedno vrlo bitno pravilo koje glasi: da potezi i postupci koje islamski vladar - halifa povlači su postupci koje čini u ime svih muslimana a ne u svoje ime, zbog toga oni ostaju validni $i$ važeći i nakon njegove smrti.

El -Maverdi je o tome rekao: „Kada halifa umre, sudije koje je postavio ostaju i dalje na toj funkciji.“ Također je rekao: „Ako je neki namjesnik bio legalno postavljen od strane halife, njegova funkcija neće prestati smrću halife, ali ako bude postavljen od strane nekog ministra, njegova služba će prestati smrću tog vezira, zbog toga što se nečija inauguracija od strane halife čini u ime svih muslimana, a od strane nekog ministra se to radi u ime tog ministra. ${ }^{\text {}} 25$

Remli je rekao: „Sudija se ne razrješava sa svoje funkcije zbog smrti halife jer halifa vlada u ime muslimana i kada umre posljedice njegovih postupaka ostaju jer su njegovi postupci urađeni u ime muslimana. S toga, njihova validnost ne prestaje njegovom smrću. “26

Imam 'Izz b. Abdusselam je rekao: „Halifa ili namjesnik ukoliko ubije nekoga ili uništi neki imetak prilikom obnašanja svoje funkcije u ime općeg dobra, dužnost - vadžib je budžeta islamske države a ne halife ili

\footnotetext{
${ }^{24}$ Maverdi, El-Ahkamus-sultanijje, str. 17.

${ }^{25}$ Maverdi, El-Ahkamus-sultanijje, str. 31., Ebu J'ala, El-Ahkamus-sultanijje, str. 19.

${ }^{26}$ Remli, Nihajetul - muhtadž ila šerhil - minhadž, 8/234.)
} 
namjesnika da to kompenzira jer su to oni počinili za vrijeme kada su radili za opću korist ili javno dobro, što u krajnjoj konsekvenci znači da su to počinili sami muslimani, a ne oni.“ 27

Iz navedenih i drugih citata islamskih pravnika da se primijetiti da su oni pravili razliku između sudija i namjesnika koji su postavljeni od strane halife i od nekih drugih državnih službenika. To je eksplicitan dokaz da su islamski pravnici koji su pisali o ustavnom pravu i državi poznavali ideju kontinuiranosti države putem kontinuiranosti njenih službenika, sudija, namjesnika, te kontinuiranosti njihovih funkcija poslije smrti halife. To znači da je po njima država kontinuirano pravno lice koje ne prestaje sa smrću vladara, tj. fizičkih lica.

Dakle, islamsko ustavno pravo je po pitanju priznanja pravnog lica državi putem kontinuiranosti funkcija njenih službenika i nakon smrti islamskog vladara preteklo savremeno ustavno pravo koje je pravno lice državi priznalo tek prije nekoliko stoljeća.

$\mathrm{S}$ toga se s pravom može konstatirati da je u islamskom ustavnom pravu Allah krajnji vlasnik vlasti: I vlast pripada samo Allahu. (El-En'am, 57.) A da tu vlast na Zemlji obnašaju ljudi kojima je On to dozvolio: $J a$ ću na Zemlji učiniti namjesnika. (El-Bekare, 30.)Mi smo te namjesnikom na Zemlji učinili, zato sudi ljudima po pravdi.(Sad, 36.)

Nakon što je Allah opunomoćio ljude tom vlašću, oni su postali vlasnici tog prava i u njemu su postali ravnopravni. Ukoliko nakon toga izaberu jednog između sebe i opunomoće ga da vrši u ime njih vlast on postaje njihov zastupnik,a oni i dalje ostaju njeni krajnji vlasnici.

Prema tome, ako taj njihov opunomoćnik postane nasilnik, ili počini nešto suprotno ustavu, ili prekrši neki od uvjeta zastupništva oni će imati pravo da ga smjene jer oni koji posjeduju pravo da nekoga inauguriraju imaju pravo i da ga razriješe te funkcije kada se ne bude držao dogovora. Ovo je upravo filozofija na kojoj počiva pravo islamskog ummeta da smjeni halifu kada se javi neki razlog koji to nalaže.

${ }^{27}$ Izuddin b. Abdusselam, Kava'idul-ahkam fi mesalihil- enam, 2/165., El-Merginani, El-Hidaje, 2/118. 
Znači, proces izbora halife i njegovo inauguriranje sa zakonske strane je ustvari proces predavanja obnašanja vlasti u ime nekoga i umjesto nekoga, što upućuje da halifa u islamskom ustavnom pravu obnaša lidersku vlast kao zastupnik i opunomoćenik, a ne u ime sebe.

\section{Pravo nadzora i smjene halife od strane islamskog ummeta}

Prije svega treba istaći da i ovo kao i sva ostala prava u islamu nije apsolutno. Ono je u samom svom nastanku i razvoju ograničeno s nekoliko ograničenja. Nastalo je prije svega kao institucija zastupništva - el-vikale, a i kod same njegove primjene ograničeno je sa uvažavanjem ili neprimjenom islamskog zakonodavstva.

Ako položaj halife u islamu ima status zamjenik i zastupnik islamskog ummeta, onda je logično da njegove sve ovlasti u svim postupcima budu ograničene s tim zastupništvom, tj. da moraju biti u njegovim okvirima, jer svi njegovi postupci moraju biti usmjereni ka primijeni šerijata. Upravo se na to i odnosi dio definicije islamskih pravnika kad definišu instituciju hilafeta kad kažu ,...zaštita vjere i upravljanje ovim svijetom.“

Ako je cijeli ummet zadužen i odgovoran za primjenu šerijata, onda je logično da i halifa bude odgovoran za to; s jedne strane što predstavlja i zastupa taj ummet u tome, a s druge što je i on jedan član tog ummeta, tj. što je musliman.

To opet implicira da svako njegovo odstupanje od šerijata ili bilo kakvo nepoštivanje obaveza preuzetog predstavništva povlači za sobom odgovornost koja počinje prvo sa kontrolom - upozorenjem a završava se sa smjenom.

Zato ćemo se prvo osvrnuti na pravo nadzora a potom na pravo smjenjivanja.

\section{Pravo ummeta na nadzor i kontrolu vladara}

Islamski ummet u islamskoj državi je u osnovi temeljni faktor koji posjeduje vlast i upravu. Sam Zakonodavac ga je zadužio da izabere svoje lidere, te da ih nadzire. Muslimani su obavezni da primijene islamski zakon, te zato imaju i pravo da ukoliko vladari koje izaberu ne primjene taj zakon, smijene ih i postave druge. 
Ako je islamski ummet, kako smo već rekli, posjednik vlasti i uprave i ako ima pravo da izabire svoje lidere da u ime njega upražnjavaju to pravo, onda je logično da vlasnik prava kontroliše svoje zastupnike koje je izabrao da bi se uvjerio da li postupaju i izvršavaju ono sa čime ih je zadužio.

Pošto je vlasnik tog prava u ovom slučaju islamski ummet koje je ograničeno sa primjenom šerijata, onda će i njegovi zastupnici biti ograničeni istim ograničenjima, jer zastupnik ne može imati veće ovlasti u okvirima zastupništva od onoga ko ga je opunomoćio. Zato islamski ummet ima puno pravo da nadzire halifu i kontroliše njegovu primjenu šerijata, njegovo pokoravanje normama islamskog ustava $\mathrm{i}$ zakona te njegovo pridržavanje istih prilikom upražnjavanja svojih zastupničkih ovlasti.

\section{Osnova na kojoj počiva pravo ummeta da kontroliše i usmjerava vlast}

Osnova na kojoj se temelji pravo ummeta da kontroliše i usmjerava vlast se može opravdati sljedećim činjenicama:

1. što vlast u osnovi u islamskoj državi pripada ummetu, a vladar je samo njegov zastupnik, a poznato je da onaj ko posjeduje neko pravo, ima pravo da nadzire svog zastupnika kojem je povjerovao to pravo.

2. što se inauguracija vladara $u$ islamskoj državi odvija putem prisege, a prisega je vrsta ugovora koji u sebi involvira preuzimanje obaveze od strane vladara da primjeni islamski zakon i to je njegova obaveze prema ummetu. S toga ummet ima pravo da ga nadzire i kontroliše koliko se vladar pridržava preuzete obaveze.

3. što ummet mora imati opravdanje pred Allahom jer je zadužen za primjenu islamskog zakona, pa ako bi prešutio njegovu neprimjenu ili kršenje od strane svoga zastupnika - halife, onda bi snosio odgovornost za to. Zbog toga je ummetu neophodno da nadzire i kontroliše svoje vladara kako ne bi bio odgovoran pred Bogom za neprimjenu Njegova zakona.

Spomenuto pravo je bilo poznato u zlatnom periodu islama. Prvi vladari islamske države su ga ne samo priznavali, nego i očajnički pozivali 
ummet da ih nadzire i usmjerava ako kod njih vide ono što nije u skladu sa islamskim zakonom.

Tako se prenosi da je Ebu Bekr, r.a., govorio: „Ako budem ispravno radio pomozite mi, a ako pogriješim ispravite me. ${ }^{\text {‘2 }}$

A od Omera, r.a., se prenosi da se jednog dana ispeo na minber i rekao: „O muslimanski skupe, šta biste rekli da ja svoju glavu okrenem ovom svijetu ovako, pa je nageo glavu?! Potom je neki čovjek ustao i rekao: „Uradili bi sa svojim sabljama ovako“, i pokazao na odsjecanje glave.Omer ga je upitao: „Je li to misliš na mene?“ Čovjek je rekao: „Da, moj se govor odnosi na tebe.“ Omer je na to rekao: „Da ti se Allah smiluje! Hvala Allahu koji je dao među mojim podanicima one koji će mi ukazati na pravi put kada skrenem. ‘29

Znači, islamski ummet ima pravo da nadzire vladara i da ga smjeni sa drugim sposobnijim od njega u slučaju ako se desi nešto što bi zahtijevalo njegovu smjenu, svejedno je da li se to ticalo moralnih ili tjelesnih nedostataka. Vladar $\mathrm{u}$ islamskoj državi se mora potpuno potčiniti zakonu i ne uživa nikakav politički imunitet koji bi ga odlikovao nad ostalim muslimanima. Status vladara u islamskom političkom sistemu se skoro ne može porediti sa statusom predsjednika države u najdemokratskijim savremenim državama. To se jasno vidi iz prvog obraćanja prvog halife islamske države, Ebu Bekra, r.a. ${ }^{30}$

\section{Pravo ummeta da razriješi vladara -halifu}

Rekli smo da islamskim ummetima pravo na kontrolu i smjenu svog vladara $\mathrm{i}$ to postepeno počevši od savjeta i sugestija pa sve, ukoliko spomenuti metodi ne budu koristili, do njegove smjene i udaljavanja, jer je ummet izabrao halifu kao sredstvo za realizaciju islamskog zakona, pa ako to sredstvo ne bude djelotvorno za realizaciju spomenutog cilja ili ga je više nemoguće koristiti, onda postaje obaveza - vadžib da se takav vladar zamjeni s drugim koji će taj cilj ostvariti.

\footnotetext{
${ }^{28}$ Ibn Hišam, Es-Siretun-nebevijje, 4/175., Sujuti, Tarihul-hulefa, str. 69., Ibn S'ad, Et-Tabekat, 3/183.

29 Tantavi, Ahbaru Omere, str. 432.

${ }^{30}$ Vidi: Sulejman Tamavi, Omer b. El-Hattab ve usulus-sijaseti vel idaretil-hadiseti, str. 267.
} 
Islamski učenjaci su saglasni oko načela razrješenja halife ukoliko počini nešto što to obvezuje. Međutim, nisu saglasili oko uzroka koji kada se nađu da li neminovno i uslovljaju njegovo razrješenje i smjenu ili ne?

Da bismo tu konstataciju potvrdili navest ćemo nekoliko njihovih mišljenja.

El-Maverdi je o tome rekao: „Ono što se smatra da mijenja njegov status, tj. halifin i izvodi ga iz funkcije hilafeta su dvije stvari:

a. promjene koje se mogu desiti u njegovoj pobožnosti i moralu,

b. tjelesne promjene.

Prva se odnosi na griješenje - fisk koje se ogleda u dvije stvari: slijeđenje strasti i nedoumice -sumnje. Pod prvom se misli na činjenje grijeha i davanje primata strastima. Onaj ko dođe u ovakvo stanje, ne može više biti halifa. Ako je već na toj funkciji, treba ga razriješiti, a ako nije, ne može biti izabran.

Pod drugom vrstom se misli na dileme oko nekih doktrinarnih stvari i objašnjenja - te'vila gdje se kod osobe jave neke sumnje, pa ih nastoji legalizovati šerijatskim dokazima tumačeći ih suprotno općeprihvaćenim tumačenjima.

Oko inauguriranja spomenute osobe na položaj halife, nemamo jedinstven stav kod islamskih učenjaka. Jedni smatraju da takav ne može biti inauguriran na taj položaj, niti može ostati na njemu ako mu se desi spomenuto stanje....."31

Šafija također smatra da se halifa treba zbog grijeha i nasilja razriješiti tog položaja. ${ }^{32}$

Gazali je rekao: „Vladar nasilnik treba da da ostavku jer mu je već radi toga mandat prestao ili se zbog toga mora smijeniti....jer on ustvari $\mathrm{u}$ tom slučaju i nije vladar.“33

\footnotetext{
${ }^{31}$ Maverdi, El-Ahkamus-sultanijje, str. 17., Ebu J'ala, El-Ahkamus-sultanijje, str. 12.

32 Teftazani, El-Akaidun-nesefijje bišerhit-Teftezani, str. 145.

${ }^{33}$ Gazali, Ihjau 'ulumid-din, 2/111.
} 
Islamski učenjaci su izričiti po tome da ummet treba smijeniti halifu i onda kada se nađe u stanju koje ga sprječava od normalnog obnašanja te funkcije kao npr. kad padne u ropstvo, itd. U takvim situacijama dužnost ummeta je da ga razriješi te funkcije i postavi drugog. ${ }^{34}$

Iz navedenih citata se jasno vidi da je načelo smjene halife radi opravdanog razloga legalno i potvrđeno $\mathrm{u}$ islamskom pravu jer ga potvrđuju jasni i kategorični dokazi. To je pravo ummeta $\mathrm{i}$ on ima ingerencije nad njime zato što ga je Zakonodavac ovlastio da postavi halifu da bi se normalizirao život i primijenio šerijat.

Međutim, nameće se jedno pitanje koje glasi: kada se nađe razlog za njegovu smjenu kada ga onda treba smijeniti? Da li će ga ummet smijeniti bez obzira na posljedice proistekle iz toga, pa makar to dovelo i do prolijevanju krvi, opće anarhije i nereda, ili za taj proces postoje pravila koja je šerijat postavio i koja se trebaju prilikom njegove realizacije uvažiti?

Načelo smjenjivanje halife zbog opravdanog razloga koji to uslovljava potpada pod instituciju naređivanja dobra i sprječavanja zla i zato će pri tom procesu tj. procesu smjene halife uvažiti ista pravila koja nalaže spomenuta institucija. Od osnovnih pravila koja se moraju uvažiti prilikom primjene te institucije je pravilo da uklanjanje jednog zla ne smije uzrokovati veće zlo. ${ }^{35}$

Dakle, samo postojanje razloga za smjenu halife ne znači nužno da se on mora odmah i smijeniti, jer se prije njegove smjene moraju uzeti u obzir; mogućnost njene realizacije, te sve posljedice koje mogu proisteći iz nje. Ukoliko se ustanovi da ju je moguće realizovati, te zaključi da će posljedice njene primjene biti neznatne u tom slučaju je dužnost - vadžib smijeniti halifu. Međutim, ako se ustanovi suprotno i utvrdi nemogućnost njene realizacije, ili mogućnost ali sa teškim, kobnim i većim posljedicama po islamski ummet od štete ostajanja takvog halife na položaju, onda neprimjenjivanje tog prava tj. smjene halifi biti obaveza -vadžib a primjena zabranjena - haram. ${ }^{36}$

\footnotetext{
${ }^{34}$ Maverdi, El-Ahkamus-sultanijje, str. 30.

${ }^{35}$ Ibn Tejmijje, Fetavi, 28/129.

${ }^{36}$ Abdukerim Zejdan, Usulud-d'ave, str. 168.
} 


\section{Monarhija i poliarhija u instituciji hilafeta}

Osnovno načelo koje se primjenjuje po ovom pitanju i koje je prihvaćeno konsenzusom je da nije dozvoljeno da $\mathrm{u}$ islamskom ummetu budu dva ili više halifa na jednom mjestu ili regiji. Na osnovu toga, ako bi se ustoličio drugi ili bilo koji halifa poslije prvog, njegovo ustoličenje ne bi bilo legalno, jer bi to vodilo razdoru i nejedinstvu muslimana. Međutim, ukoliko bi se radilo o različitim podnebljima i regijama koje su međusobno udaljene jedna od druge, u tom slučaju neki islamski pravnici to zabranjuju, dok drugi vide u tome mjesto za idžtihad.

Navest ćemo nekoliko mišljenja koja to potvrđuju. Bagdadi je rekao: „Nije dozvoljeno da u isto vrijeme i na istom mjestu budu dva vladara kojima je dužnost pokoriti se...Međutim, ako bi dvije regije razdvajalo more koje bi spriječilo dolazak pomoći svakom od njih, onda bi bilo dozvoljeno stanovnicima svake te regije da izaberu sebi halifu. “37

El - Maverdi je rekao: „Ako bi se ustoličila dva vladara u dvije regije, nijedno ustoličenje ne bi bilo validno, jer nije dozvoljeno da islamski ummet $\mathrm{u}$ isto vrijeme ima dva vladara iako je to dozvoljeno po nekim raritetnim mišljenjima.“38

Osnova na kojoj su islamski učenjaci donijeli opće pravilo i prihvatili ga konsenzusom da nije dozvoljeno islamskom ummetu imati više halifa $u$ isto vrijeme $i$ na jednom mjestu su mnogobrojni ajeti i hadisi koji pozivaju vjernike na jedinstvo i zabranjuju im razjedinjenost, poput sljedećih ajeta $\mathrm{i}$ hadisa:

Svi se čvrsto Allahova užeta držite $i$ nikako se ne razjedinjujte! (Ali Imran, 103.)Ne budite kao oni koji su se razjedinili $i$ u mišljenju podvojili. (Ali Imran, 105.)I pokoravajte se Allahu i Njegovu Poslaniku, $i$ ne prepirite se da ne biste klonuli $i$ bez borbenog duha ostali. (ElEnfal, 46.)

Poslanik, s.a.v.s., je rekao: „Ako se ustoliče dva halife, ubijte posljednjeg!“ (Muslim),,Ako vam neko dođe kad ste jedinstveni i htjedne da vas razjedini, posijecite ga sabljom ko on bio.“ (Muslim)

\footnotetext{
${ }^{37}$ Bagdadi, Usulud-din, str. 274., El-Džuvejni, El-Iršad ila kavati'il-edilleti fil-i'tikad, str. 425.

${ }^{38}$ El -Maverdi, El-Ahkamus-sultanijje, str. 7.
} 
Ovo načelo je općeprihvaćeno i oko njega ne smije biti dilema i nedoumica poslije jasnih i kategoričnih tekstova kojiga potvrđuju.

Međutim, mnogi islamski pravnici primjećuju na osnovu stvarnosti koju su doživjeli da je jedinstvo ummeta u mnogim vremenima i prilikama nemoguće ostvariti, zbog toga su dozvolili da bude više halifa pod uvjetom da teritorija koju drže muslimani bude prostrana.

Ono što potvrđuju historijske prilike je da postojanje više halifa u određenim prilikama i vremenima bilo bolje i uspješnije za ummet, jer se reformirao, sredio svoje stanje i prilike i ojačao upravo zbog postojanja više tih političkih identiteta koje su ga činile.

Ako se već dozvoli postojanje više halifa, i to samo radi općeg interesa naroda, a nikako radi pojedinaca i njihovih interesa, onda treba nastojati da se ujedine ciljevi i interesi. Od najvažnijih tih ciljeva je da se bude jedinstveno naspram neprijatelja, $\mathrm{t} j$. da se ima jedinstvena obrambena $i$ vanjska politika.

Obrambeni savezi, ekonomske unije, politički regionalni interesi, itd., su danas poznati na sceni savremenih političkih zbivanja. S toga je obligatna vjerska obaveza današnjem islamskom ummetu da između sebe iznađe i sklopi sve one saveze i unije koje će voditi realizaciji odbrambenih ciljeva, jedinstvene politike i osigurati snagu i čast ummetu kao i autoritet kod njegovih neprijatelja kako bi bio spreman, ako mu se jednog dana pruži prilika, ostvariti svoj krajnji cilj i ujediniti se u pravom smislu.

\section{Prisilno priznanje halife ili priznanje iz nužde}

Ovdje se aludira na priznanje vladara koji se samoinicijativno proglasi za halifu i odcijepi od matice. Islamski pravnici su spomenuto pitanje aktualizirali posebno za vrijeme abasijskog perioda vladavine kada se je pojavilo više samostalnih islamskih država.

Zaključili su da bi pravno i politički bilo vrlo rizično u potpunosti proglasiti neustavnost takve vrste hilafeta jer bi značilo zanemarivanje novonastale stvarnosti i bježanje od iznalaženja rješenja za nju. Shvatili su da je veća korist priznati takvog vladara od šteta koja bi proistekla od njegova nepriznanja. 
Sve to potvrđuje jednu širinu i fleksibilnost islamskog prava i njegovu spremnost da se suprotstavi i iznađe rješenje za svaku novonastalu situaciju i problem. Islamsko pravo u odnosu na novonastale političke prilike i društveni razvoj ne smije biti statično, a niti konzervativno, pa da se fokusira samo na jedan oblik političkog sistema - na oblik tradicionalnog hilafeta. Naprotiv, islamsko pravo je bilo spremno i dovoljno široko da prihvati i drugačije oblike političkih sistema koji su vladali islamskom državom ili druge sisteme koji su derivirani iz tradicionalnog. Tako je islamsko ustavno pravo uspjelo da $\mathrm{u}$ novonastalim situacijama, a posebno u vjerskim i pravnim normama koje su izdavale te novonastale države, da validnost nakon njihove nevalidnosti i učini ih legalnim nakon što su bile nelegalne. Na taj način se od ljudi uklonila poteškoća, njihov život se uskladio sa vjerskim načelima, očuvalo se minimalno jedinstvo ummeta, jedinstvo u općim stvarima i interesima umjesto razjedinjenosti i netrepeljivosti i tako se uspjelo ostati jedinstvenim u borbi protiv zajedničkog neprijatelja.

Iz izloženog se vidi da su se islamski pravnici u novonastalim prilikama našli, hajde da kažemo, između dvije vatre ili između dva zla i zato su bili prisiljeni da balansiraju između njih i odaberu manje.

Imali su da biraju između da prihvate da je novonastala vlast neustavna i pored toga što ona u stvarnosti postoji što bi imalo za posljedice da sve sudske presude budu neustavne kao i svi postupci koje poduzimaju namjesnici $u$ ime općeg interesa muslimana. To bi značilo da se blokiraju svi međuljudski odnosi i aktivnosti koje čine ljudski život normalnim i na taj način bi se indirektno proglasio i politički i društveni život mrtvim.

Ili nasuprot tomu da zauzmu suprotan stav i donesu mišljenje na osnovu stvarnosti, te da postojećem sistemu daju i priznaju ustavnost kako bi mogli spasiti ono što se može ili što je vadžib spasiti. Pored svega toga oni su bili svjesni da je to samo privremeno priznanje takve vlasti čija ustavnost je u korelacijskoj vezi sa postojanjem vanrednih prilika koje kada prođu i takva vlast automatski mora izgubiti svoju privremenu ustavnost, jer su je priznali iz nužde koja zabranjene stvari čini dozvoljenim.

O tome je Gazali rekao: „Ako se kaže da ste zanemarili svojstvo znanja kod izbora halife, onda vas to logično obvezuje da zanemarite i vjeru i 
moral kao i ostala svojstva koja se uslovljavaju kod izbora halife.“ Odgovorit ćemo: „To nije dobrovoljno i namjerno toleriranje, nego su to nužde koje dozvoljavaju zabranjene stvari. Mi znamo da je jedenje mesa uginulih životinja zabranjeno, ali je smrt veća šteta od njegova konzumiranja. Da mi je samo znati ko se s time ne slaže i ne priznaje hilafet koji se pojavio u naše vrijeme zbog neispunjenja uvjeta koje se uslovljavaju kod izbora halife, a u isto vrijeme je nemoćan da mu se suprotstavi i da ga zamijeni...Pa koje je od ta dva stanja bolje: da se kaže da su sve državne sudije i institucije neustavne, brakovi nevalidni, svi postupci koje su državni službenici sklopili i načinili u cijeloj državi obustavljeni i da cijeli ummet čini haram, ili je bolje prihvatiti da je takav hilafet ustavan $\mathrm{i}$ da su sve radnje koje se poduzimaju pod njegovom ingerencijom legalne na osnovu činjeničkog stanja i nužde... ‘39

\section{Priroda i vrsta političkog sistema u islamu}

Ovdje se nužno osvrnuti i odgovoriti na pitanje koje se nameće kad se govori o bilo kojem političkom sistemu pa tako i o islamskom, gdje se nalazi suverenitet ili vrhovna vlast u tom sistemu? Međutim, prije odgovora na postavljeno pitanje smatramo da bi trebalo odgovoriti prije na jedno drugo pitanje: pod koju vrstu političkih sistema bi se mogao svrstati islamski politički sistem. tj. koji bi mu naziv najbolje odgovarao? Da li je politički sistem islamske države demokratski, teokratski, autokratski ili neki drugi oblik?

Orijentalisti su islamski politički sistem nazivali različitim imenima. De Santilana je rekao da je islamska država teokratska.(The Legacy of Islam, p. 286.) Profesor W. Muir smatra da je islamska država autoktratska i tiranijska.(The Califate, p. 600., D.B.Macdonald, Development of Muslim Theology, p.58.)

Međutim, sigurno je da islamska država nije teokratska, jer teokratska država podrazumijeva božansku vladu predstavljenu u crkvenom kleru ili nekim duhovnim svecima poput države papavata koje su bile $\mathrm{u}$ Evropi u srednjem vijeku. Ti duhovni predstavnici su imali apsolutni monopol nad duhovnim - vjerskim stvarima i na osnovu toga imali su

${ }^{39}$ Gazali, El-Iktisad fil-i'tikad, str. 137-138. 
pravo na oprost i herezu. Pokornost njima je bila neupitna, a njihova mišljenja su bila zakon jer su tvrdili da predstavljaju Božiju volju na Zemlji.

Sve te osobine se ne mogu pripisati islamskoj državi jer u njoj ne postoji svećenstvo, niti ima bilo ko u islamu monopol nad vjerom, a niti uživa posebne vjerske privilegije. Vladar u islamskoj državi je lice koje primjenjuje islamski zakon, kome se i ne mora pokoriti u određenim situacijama. Postavljen je na taj položaj od strane ummeta i zato ummet ima pravo da ga smijeni. Pravo idžtihada u islamu je priznato, a volja ummeta izražena o obliku konsenzusa se uvažava i ona je temeljni dio islamskog zakona. Sve navedene i druge stvari koje smo rekli o islamu su u potpunoj suprotnosti sa teokratskom državom.

Islamska država u bukvalnom smislu nije ni država zakona, tj. pravna država. Iako je ova vrsta države najbliža islamskoj jer je islamska država postavljena na sistemu i zakonu i njen osnovni cilj je uspostava tih sustava, ali joj ipak taj atribut u potpunosti ne odgovara. Tekstovi islamskog zakona nisu nefleksibilni, niti su konačno definirani a niti posebni, tj. ne sadržavaju za svaku situaciju i problem posebnu pravnu normu. Sadržavaju veoma široko prostor za pravna objašnjenja, definiranja, dodavanja i inovacije i to sve putem pravnog, individualnog promišljanja - idžtihada. U isto vrijeme, u islamskom zakonu i pravna ličnost ummeta je priznata a njegovu opću volju upotpunjuje zakon. Ustvari, ona je ta koja ga primjenjuje i predstavlja. Ona je ta koja bira vladara i daje mu inauguraciju, usmjerava ga, nadzire i smjenjuje. Prema tome, ummet u islamskoj državi ima vidljiv utjecaj u političkom segmentu, a sve spomenuto se ne može pripisati apstraktnom zakonu niti pukim njegovim tekstovima.

\section{Islam i demokratija}

Između islama i demokratije postoje mnoge sličnosti i identičnosti. Međutim, ta konstatacija odražava samo jedan dio istine. Potpuna istina o tome je da između dva sistema postoji toliko sličnosti koliko i diferenciranosti, a čak se može s pravom konstatirati da ima više različitosti nego sličnosti.

Što se tiče sličnosti, već smo u našem dosadašnjem izlaganju spomenuli mnoge od njih, poput društvenog ugovora o osnivanju države između 
naroda i vladara koji je izboran i obavezan za obje strane, odgovornost vladara, itd. Međutim, ako se pod demokratijom danas misli na vladavinu naroda putem naroda $\mathrm{i} u$ ime naroda, onda to značenje involvira politički sistem islamske države s izuzetkom naroda, jer narod $\mathrm{u}$ islamu treba poimati na jedan definiran i sveobuhvatan način kako ćemo to objasniti kasnije.

Ako demokratija danas znači postojanje određenih političkih i društvenih načela poput načela jednakosti pred zakonom, slobodu vjerovanja i mišljenja, realizaciju pravde, ili garanciju određenih prava poput prava na život, slobodu, posao, itd., onda nema dileme da sve to postoji i u islamskom političkom sistemu. O nekima smo već govorili.

Međutim, ono što treba imati na umu kod ovih prava je to da se islamska teorija o njihovom nastanku razlikuje od teorije njihova nastanka $\mathrm{u}$ drugim političkim sistemima. Islam smatra da su ljudska prava Allahovi darovi ljudima i dijeli ih na tri vrste: Allahova prava, zajednička prava gdje su spojena čovjekova i Allahova prava i ljudska prava. Ali i pored toga cilj im je isti - osiguranje spomenutih prava, jer krajnja intencija islamskog zakona je da ostvari apsolutnu pravdu koliko god je to moguće i da čovjeku pribavi i obezbijedi najčasniji i najplemenitiji život dostojan njegove ljudskosti.

Ako demokratija znači načelo razdvajanje državne vlasti, onda je i to prisutno i vidljivo $\mathrm{u}$ islamu. Zakonodavna vlast, koja se smatra najvažnijom vlasti $\mathrm{u}$ demokratskom sistemu, pripada islamskom ummetu i ona je potpuno odvojena od predsjednika države - halife. Zakonodavstvo se u islamu uzima iz Kur'ana, sunneta, konsenzusa ili idžtihada. Prema tome, ono je potpuno samostalno od vladara i čak je iznad njega. Ono ga obavezuje i ograničava.

Vladar islamske države je ustvari izvršna vlast. Sudska vlast je također samostalna, jer ona ne sudi po hiru vladara ili predsjednika, nego po islamskom zakonu i ne može se nikako zamisliti ustavnost sudstva u islamskoj državi ako ne bude sudilo po islamskom zakonu.

\section{Oblik državnog političkog sistema u islamu}

Velika je greška i zabluda misliti da su islam i demokratija u potpunosti identični i kompatibilni. Među dva sistema postoje mnogobrojne bitne i suštinske razlike. Međutim, mi ćemo se osvrnuti samo na najbitnije: 
Prvo - u savremenim zapadnjačkim demokratijama danas se riječ narod odnosi na ljude koji žive na jednom prostoru u određenim geografskim granicama kojeg povezuju krvne, nacionalne i jezičke veze i zajednička tradicija i običaji. Dakle, sistem domokratije se veže za pojam nacionalnosti ili rasizma koji obično poprima naznake fanatizma $\mathrm{i}$ pristrasnosti.

Takvo značenje je nemoguće naći u islamu. Narod - ummet $\mathrm{u}$ islamu se uopće ne povezuje sa mjestom boravka, krvlju, jezikom, itd., jer su to umjetne, interesne ili drugorazredne veze. Osnovna veza oko koje islam okuplja i klasificira ljude je jedinstvenost doktrine, tj. ideje i osjećaja. Tako da svako ko primi islam, bez obzira koje nacije, boje i iz koje države bio, automatski postaje članom islamskog naroda - ummeta a u krajnjoj konsekvenci i državljaninom islamske države.

Prema tome, islamski pogled na narod je bez sumnje pravedniji, ljudskiji i humaniji a njegovi horizonti su internacionalnih a ne nacionalno - lokalnih dimenzije. Ali i pored toga, sve to ne sprječava da unutar tog širokog kruga postoje posebni manji krugovi regionalnosti i nacionalnosti, jer od njih ponekad može zavisiti realizacija općeg interesa, pa oni u tom slučaju postaju vadžibom.

Drugo - ciljevi savremene ili bilo koje demokratije su ovosvjetski ili materijalistički. Oni imaju za cilj da ostvare sreću i blagostanje određenom narodu udovoljavajući njegovim materijalnim ovosvjetskim potrebama što zahtijeva maksimalno iskorištavanje prirodnih resursa, podizanje cijena usluga ili pribavljanje tih koristi putem rata.

Na drugoj strani, islamski politički sistem, ili ako se može reći islamska demokratija, ima za cilj sve spomenute interese dajući im odgovarajuću važnost koja im i pripada, ali u isto vrijeme ona zanemaruje nacionalnu pristrasnost i ima za cilj pored ostvarenja svih tih materijalnih ciljeva ostvarenje i duhovnih. Čak se može reći da su ti duhovni ciljevi esencijalni i da su osnova. S toga, islamska država kroz sve svoje postupke mora imati na umu i onaj svijet i znati da je on glavni cilj, koji se realizuje isključivo primjenom svega onoga što islamski zakon naređuje, tj. onoga što vodi ka Allahovom zadovoljstvu i putem čega se ostvaruju ljudske duhovne potrebe. Također, islamska država mora uzeti vjeru i moral kao mjerilo za sve svoje postupke i djela. 
Treće - vlast naroda u zapadnjačkim demokratijama je apsolutna i neograničena. Narod apsolutno i uvijek ima suverenitet. On ili parlament kojeg izabere donose zakone i poništavaju ih, a odluke koje donese parlamenti postaju zakonima koji se moraju primijeniti i kojima se mora pokoriti pa makar bili suprotni moralnim principima i načelima ili općem ljudskom interesu. Tako npr. savremena demokratija objavljuje rat radi nametanja svog suvereniteta nad drugim narodom, radi monopola nad ekonomskim tržištem, radi okupacije neke države ili monopola nad naftnim izvorima. Na putu realizacije tih svojih ciljeva se neprestano lije nevina krv, gube se bezbrojni nevini životi i zbog toga dovodi cijelo čovječanstvo u nesreću.

$\mathrm{S}$ druge strane, $\mathrm{u}$ islamu narodna vlast nije apsolutna i neograničena. Nju ograničava islamski zakon, tj. vjera koju je dobrovoljno prihvatio svaki pojedinac islamskog ummeta. Narod se u islamu ima pravo kretati samo $\mathrm{u}$ okvirima tog zakona. Islamski ummet je $\mathrm{u}$ političkom islamskom sistemu ili islamskoj demokratiji ograničen i sa moralnim načelima i principima. Islam je odredio narodu prava i dužnosti koje mora uvažavati ako žele da ostane u njegovim okvirima.

Četvrto - islam je priznao demokratska sredstva kojima se realizuje i štite osnovna načela islamske demokratije i ustavnost.

Tako je islam odredio da vladar islamske države mora biti izabran od strane ummeta $\mathrm{i}$ to putem prisege $-b_{e j}{ }^{\prime}$ o c čijoj biti i prirodi smo već govorili.

S tim što islam ne sprječava ummet da izvrši i realizuje to pravo na način koji najbolje odgovara prilikama i vremenu u kom se realizuje, jer su njegova pravila i norme načelne. Zbog toga islam nema ništa protiv da se izbor halife izvrši direktnim ili indirektnim glasanjem.

\section{Pravo na kandidaturu i glasanje}

Savremeni islamski pravnici nemaju jedinstven stav po pitanju dozvoljenosti da neko sebe kandiduje za predsjednika islamske države ili za vijeće šure. 
Jedni smatraju da to nije dozvoljeno, jer postoji eksplicitna zabrana da se za sebe traži neka funkcija ili položaj. ${ }^{40}$

Drugi pak misle suprotno, smatrajući to samo nečijom aplikacijom i oglašavanjem nekoga da ispunjava uvjete koji ga čine kompetentnim za funkciju za koju aplicira.

To se također, može shvatiti i kao ukazivanje ummetu na dobro i na ono što je bolje za njega, jer je i Allahov poslanik Jusuf, a.s., kandidirao sebe i rekao: Postavi me da vodim brigu o stovarištima u zemlji, ja sam zaista čuvaran i znan. (Jusuf, 55.)

Neki od onih koji zastupaju ovo mišljenje smatraju da je to apsolutno dozvoljeno, dok neki suvremenici to dozvoljavaju iz nužde kao izuzetak iz općeg pravila. Svoj stav opravdavaju današnjom specifičnom situacijom u kojoj je teško znati ko je kompetentan, a ko nije za određene funkcije. ${ }^{41}$

Smatramo da je drugo mišljenje ispravnije zbog dokaza koje su podastrli. Što se tiče pak hadisa kojim prvo mišljenje argumentuje svoj stav, može se reći da se odnosi na one koji traže položaj i vlast radi svojih ličnih interesa $\mathrm{i}$ šićara, a ne na one koji ga traže radi općeg interesa i koristi, kao i na one koji nisu dostojni tih funkcija. Pored svega toga, primjećuje se da je zabrana traženja vlasti obrazložena i u nekim dokazima koji to pitanje tretiraju, što znači da traženje vlasti samo po sebi nije zabranjeno, nego se ono zabranjuje zbog obrazloženja koja su spomenuta u njima poput kajanja na Sudnjem danu i slabosti, tj. neispunjavanja uvjeta koji se traže za nju.

\section{Pravo glasa u islamskom političkom sistemu}

Svaki musliman koji je punoljetan i pametan, svejedno kojeg roda bio, u osnovi ima pravo da svojim glasom učestvuje u kreiranju sudbine islamske države, jer se ummet sastoji od pojedinaca, a rekli smo da

\footnotetext{
${ }^{40}$ Pogledaj: Muhammed Asad, Minhadžul-islami fil-hukmi, str. 91., Mevdudi, Nazarijetul-islamis-sijasijje, str.59., Abdul-Kadir 'Avde, El-Islam ve evda'una essijasijje, str. 168.

${ }^{41}$ Pogledaj: Abdul-Kerim Osman, En-Nizam es-sijasi fil-islam, str.39., Abdul-Kerim Zejdan, El-Ferdu ved-devletu fiš-šeri'atil-islamijje, str. 32., Muhammed Abdullah elArabi, Nizamul-hukmi fil-islami, str. 73.)
} 
pravo izbora halife pripada upravo ummetu. Svi muslimani su ravnopravni, pa s toga svi imaju pravo glasa. Međutim, pošto je glasanje jedan vid svjedočenja, onda je nužno istaći da onaj čije se svjedočenje ne prima, nema pravo ni da glasa, jer uvjeti koji se uslovljavaju za svjedoka uvjetuju se i za glasača. Prema tome, na osnovu spomenutog pravo glasa nema onaj nad kim je izvršena kazna za potvoru, nemusliman koji nije građanin islamske države, dijete i luđak jer se od njih po šerijatu ne prima svjedočenje.

Što se tiče prava žena na glas, ono je načelno potvrđeno u 282. ajetu sure El-Bekare. A također je poznato da su žene na Drugoj Akabi dale prisegu Poslaniku, a.s., kao i muškarci.

Peto - islam je dozvolio islamskom ummetu da učestvuje u vršenju vlasti. Već smo rekli da pravo na vlast pripada ummetu, a da su vladari obični njegovi građani kojima vlast donosi samo dodatni teret $\mathrm{i}$ odgovornost pred Allahom i svim muslimanima. Ummet ima pravo obnašati svoje pravo na dva načina, kako smo to već i objasnili, a - da direktno učestvuje u vlasti kod nekih pitanja, b - da to učini posredstvom svojih predstavnika.

\section{Indirektno obnašanje vlasti}

Objasnili smo da je vladar u islamskom političkom sistemu zastupnik ummeta, vrši i obnaša tu funkciju u njegovo ime. On ga je opunomoćio da umjesto njega vrši to njegovo pravo. Tom načinu upravljanja se $u$ islamskom političkom sistemu pribjeglo zbog toga što je bilo nemoguće da cijeli ummet obnaša neke državne funkcije i učestvuje u njima.

Treba naglasiti da islam ne priznaje vladaru posebne lične privilegije poput imuniteta ili personalnih prava jer sva vlast i sve što je u vezi s njom pripada isključivo ummetu i on je jedini njen vlasnik i ima jedini pravo da opunomoći svog zastupnika koji će te dužnosti u ime njega izvršavati.

\section{Direktno obnašanje vlasti}

Islam priznaje ummetu i direktno obnašanje vlasti u cilju donošenja nekih obvezujućih sudbonosnih odluka koje ga se tiču. Takav način obnašanja vlasti desio se još za vrijeme Poslanika, a.s. Npr. Poslanik, 
s.a.v.s., je izložio pitanje načina vođenja bitke na Uhudu; da li da se vodi unutar ili izvan Medine. Te pitanje borbe protiv Kurejševića na dan Hudejbijje kada je do njega doprla vijest da su Kurejševići ubili Poslanikova izaslanika Osmana b. Affana. To se isto desilo i neposredno poslije smrti Poslanika, s.a.v.s., kada je Ebu Bekr ustao i rekao: „....Muhammed je umro i otišao svojim putem. Neophodno je u ovoj vjeri postaviti nekoga ko će bdjeti nad njom, zato razmislite o tome i dajte svoja mišljenja." ${ }^{42}$

Šesto - Pravo ummeta da nadzire i smijeni vladara. O tome smo već govorili i nema potrebe ponovo se osvrtati na to.

Sedmo - dvodimenzionalna odgovornost i ummeta i vladara.

Osmo - islamski zakoni imaju i vjersko obilježje što ima za posljedice da se suprotstave strastima, zabludama, tiraniji i pristranosti, te većoj njihovoj autoritativnosti, svetosti i nepovrjedivosti, kao i to da im se dobrovoljno i sa takmičarskim duhom pokoravaju oni nad kojim se primjenjuju.

Deveto - njihovo postojanje je opći interes kako za pojedinca i zajednicu tako i za državnički aparat. Dakle, islamski politički sistem posjeduje cjelokupan sustav odgoja građana svake države koja ga primijeni, što nije slučaj sa savremenom državom koja to ne posjeduje. Savremena država ima za cilj odgojiti dobra građana, a islamska država dobra čovjeka i vjernika. To islamska država postiže preko svoja tri sistema: doktrinarnog, obredoslovnog i moralnog islamskog sistema.

Deseto - načelo samostalnosti vlasti u islamskom političkom sistemu Iako se ovo načelo zbog svoje važnosti smatra glavnom odlikom i najvažnijim pitanjem savremenog demokratskog sistema, jer se preko njega ostvaruje garancija zaštite ljudskih prava i sloboda i ograničava apsolutizam vladara, ipak se s pravom može konstatirati da to načelo nema toliki značaj u islamskom političkom sistemu.

Monteski i drugi koji se pozivaju na spomenuto načelo pretpostavlja da svako ko ima i posjeduje neku vlast po prirodi je sklon da je

${ }^{42}$ Ibn Hišam, Es-Siretun-nebevijje, 3/780. 
zloupotrijebi. Da bi se ta zloupotreba ograničila ili izbjegla, oni su predložili princip podjele državne vlasti.

Međutim, na drugoj strani islam je prilikom hospitalizacije te bolesti pribjegao drugačijoj terapiji.

Islam smatra da su motivi koji navode na zloupotrebu vlasti moralnog karaktera. Da je to jedna moralna devijacija koju treba liječiti, a ne samo ublažavati njene posljedice. Islam je za njeno liječenje propisao nekoliko pravila i načela, koja su ustvari jedan miks zakonodavnih, pravnih i duhovnih normi, a od kojih su:

- da se volja onoga koji posjeduje neku vlast u islamskom sistemu ne smatra zakonom, pa da putem nje zloupotrebljava ovlasti ili tiraniše, jer je vladar $\mathrm{u}$ islamskom političkom sistemu samo izvršilac islamskog zakona u kojem on nema pravo ni dodati šta, a niti oduzeti.

- da se u islamskom političkom sistemu zabranjuje preuzimanje vlasti od strane onog koji nije moralan i sposoban. Uzvišeni je rekao: Najbolje je da uzmeš onoga koji je snažan i povjerljiv. (El-Kasas, 26.)

- da je u islamskom političkom sistemu za zloupotrebu vlasti propisana dvodimenzionalna eshatološka tj. onosvjetska od strane Allaha i ovosvjetska oličena u pravo ummeta da ga smijeni i sudi mu za prijestupe koje počini.

\section{Temelji na kojima počiva načelo razdvojenosti vlasti u islamu}

Načelo razdvojenosti vlasti u islamu zasniva se na dva osnovna temelja. Prvo - sudska vlast $\mathrm{u}$ islamskom političkom sistemu je odvojena od izvršne i zakonodavne na jedan neisključiv i uzajamno ovisan način. Islamski zakon, iako je u osnovi predstavljen u Kur'anu i sunnetu, ipak mudžtehidi u njemu imaju pravo da vrše neke vidove idžtihada poput pravnog tumačenje tekstova, izvođenje šerijatskih normi ili pravnih pravila za novonastale situacije za koje ne postoje posebni pravni tekstovi.

Halifi je također ako je mudžtehid dozvoljeno baviti se spomenutom vrstom idžtihada. Zakonodavna vlast $\mathrm{u}$ islamskom političkom sistemu ima pravo da nadzire izvršnu vlast i prati primjenu islamskih zakona kao što ima pravo i da je osudi ako zapazi i nađe neke proturječnosti i 
neustavnosti. Izvršna vlast predstavljena u halifi ima pravo da donese i neke zakone. Prema tome, te dvije vlasti nisu apsolutno odvojene i isključive, to je jedna vrsta blago upotpunjavajuće odvojenosti. Bez sumnje, takva vrsta odvojenosti između te dvije temeljne vlasti $u$ islamskoj državi štiti prava i slobode ljudi, jer se one međusobno nadziru i kontrolišu i na taj način se sprječava da bilo koja od njih počini nasilje i učini tiraniju i autokratizam - pojave koje se javljaju u sistemu gdje su spomenute vlasti potpuno i apsolutno razdvojene.

Drugo - centralizacija dvije vlasti - sudske i izvršne u jedno tijelo ili njihovo razdvajanje na dvije posebne vlasti u islamskom političkom pravu se svrstava pod instituciju mubaha, tj. obje stvari su dozvoljene pod uvjetom da iz toga ne proisteknu neželjene posljedice.

Ibn Haldun je rekao: „Na početku islama halife su vršile sudsku vlast $\mathrm{i}$ nisu je prepuštali drugima. Prvi ko ju je prepustio drugom bio je Omer. Tako je za kadiju u Medini postavio Ebu Derdaa, Šurejha u Basri, Ebu Musa el-Eš'arija u Kufi i tada je napisao poznatu sudsku povelju koja faktički sadržava većinu sudskih normi. “43

Iz spomenutog citata se vidi da je objedinjavanje dvije vlasti - izvršne i zakonodavne $\mathrm{u}$ jednu instituciju dozvoljeno $\mathrm{i}$ tako se je postupalo $\mathrm{u}$ prvom periodu islama, a dozvoljeno je i njihovo razdvajanje što se desilo za vrijeme Omera, r.a.

Vladar i pored toga što je predsjednik obje vlasti i izvršne i sudske, kao i sudija se moraju pokoriti islamskom zakonu koji ima suverenitet nad njima. Pa ako sudija zanemari taj zakon, vladar će ga upozoriti na to. A također, i sam vladar može biti procesuiran za bilo koji prijestup svejedno bio on građanske ili krivične prirode.

Razlog koji je naveo vladare $\mathrm{u}$ islamskom političkom sistemu da razdvoje vlasti nije bio zloupotreba ovlasti kao što je slučaj u drugim političkim sistemima. Ibn Haldun veli da su se oni odlučili na taj korak zbog velike prezauzetosti sa drugim stvarima pa su bili prisiljeni da neke ovlasti prepuste drugima kako bi sebi olakšali i mogli se temeljitije posvetiti drugim općekorisnim stvarima. ${ }^{44}$

\footnotetext{
${ }^{43}$ Ibn Haldun, El-Mukaddime, str. 220.

${ }^{44}$ Pogledaj, Ibn Haldun, El-Mukaddime, str. 221.
} 
Objedinjavanje spomenute dvije vlasti u jednu instituciju ili njihovo razdvajanje $u$ islamskom političkom sistemu nije definitivna i konačna stvar što znači da je dozvoljeno odabrati onaj princip koji je bolji i svrsishodniji prilikama i uvjetima u kojima se primjenjuje.

Međutim, kada se govori o načelu objedinjavanja vlasti u jednu instituciju, nužno je da se pored toga stavi i institucija šure kako bi se upotpunila slika tog sistema, jer je islamski sistem integralan i da se ne bi shvatio pogrešno nije dozvoljeno promatrati ga parcijalno. Zato je nužno vladaru da se savjetuje sa savjetodavnim vijećem ehlul-halli vel$a k d i$ kao što je dužnost i savjetodavnog vijeća da ga posavjetuje. Na taj način se stvara druga garancija za sprječavanje tiranija i autokratizam. Međutim, ako vladar zanemari instituciju šure islamski učenjaci su saglasni da ga u tom slučaju treba smijeniti. Ibn Atijje je rekao: „Šura je osnovni temelj islamskog zakona i pravnih normi pa ako se vladarne savjetuje sa učenjacima dužnost ga je smijeniti.“ A na to je Kurtubi rekao: „Oko toga nema nikakve dileme.“45

Treba imati na umu i historijske činjenice koje potvrđuju da objedinjavanje dvije spomenute vlasti nije bilo samo po sebi štetno. Naprotiv, to je bilo jedno sredstvo da se uspostavi pravda i sloboda, te da se da svakom pravo koje mu pripada i da se sve stavi na mjesto koje mu odgovara. To se sve praktično i realno ostvarilo za vrijeme četverice pravednih halifa. Također nam i historijske činjenice potvrđuju da je razdvajanje vlasti bilo i sredstvo za tiraniju i nasilje kao što se desilo u Francuskoj za vrijeme totalitarnih monarhija.

Prema tome, objedinjenje dvije vlasti može biti korisno ili štetno, zavisno od toga u čijim rukama se nađu. Pravedne halife su imali u svojim rukama obje vlasti, ali nije zabilježeno da su ikome nanijeli nepravdu i nasilje, jer su bili ograničeni Kur'anom kog su čitali svakog dana: Neka vas mržnja koju prema nekim ljudima nosite nikako ne navede da nepravedni budete! Pravedni budite, to je najbliže bogobojaznosti. (El-Maide, 8.)

${ }^{45}$ Kurtubi, El-Džami'u li ahkamil-Kur'ani, 4/249. 


\section{Umjesto zaključka}

\section{Pravo suvereniteta $\mathrm{u}$ islamskom političkom sistemu}

Islamski politički sistem, kako smo naprijed utvrdili, nije identičan ni sa jednim drugim oblikom političkog sistema, te s toga suverenitet $u$ islamu ne pripada halifi - vladaru, jer politički sistem u islamu nije autokratski, niti bukvalno zakonski, a niti suverenitet u njemu pripada samo narodu kakav je slučaj u demokratskom sistemu.

Smatramo da je najispravnije reći da je suverenitet $\mathrm{u}$ islamskom političkom sistemu dualan, tj. da pravo nad njim imaju dvije strane zajedno. Ta povezanost je nužna, jer je nemoguće zamisliti islamsku državu i njen opstanak bez te uzajamne dvojnosti. Dakle, pravo na suverenitet $\mathrm{u}$ islamskoj državi pripada narodu s jedne strane, kao i islamskom zakonu - šerijatu s druge strane.

Prema tome, islamska država je država sa jedinstvenim oblikom političkog sistema koji je specifičan samo za islam. Na osnovu toga nije dozvoljeno tvrditi da je on podudaran sa bilo kojim drugim oblikom političkog sistema, pa se s toga on mora označiti i nazvati posebnim terminom koji će odražavati istinsku njegovu bit i suštinu. Pošto se to još do sada nije desilo, onda je dovoljno da se nazove samo islamskim sistemom, ili islamskom demokratijom koja u sebi objedinjuje ljudskost - humanost, internacionalnost, vjersku dimenziju, moral, duhovnost $\mathrm{i}$ materijalnost.

\section{Literatura:}

1. Korkut, Besim, Kur'an s prevodom, Kompleks Hadimul-haremejeniššerifejnil- melik Fahd, Medina.

2. Abdul-Kadir 'Avde, El-islam ve evda'una es-sijasijje, drugo izdanje, Mektebtu daril-'urube, Kairo, 1951. god.

3. Abdul-Kerim Osman, En-Nizam es-sijasi fil-islam, prvo izdanje, Darul-iršad, Bejrut, 1968. god.

4. Abdul-Kerim Zejdan, El-Ferdu ved-devletu fiš-šeri'atil-islamijje, prvo izdanje, Matbe'atu Selman el-E'azami, Bagdad.

5. Abdukerim Zejdan, Usulud-d'ave, drugo izdanje, Matbe'atu Selman elE'azami, Bagdad, 1972. god. 
6. Bagdadi, Usulud-din, prvo izdanje, Metbe'atud-develeti fi Istanbul, 1928. god.

7. Džurdžani, Šerhul-Mevakif, Darul-kutubil-ilmijje, Bejrut.

8. Džuvejni, El-Iršad ila kavati'il-edilleti fil-i'tikad, hakkakahu ve 'alleka 'alejhi dr. Muhammed Jusuf Musa ve Ali Abdulhamid, Matbe'alHandži, Kairo, 1950. god.

9. Gazali, Ihjau 'ulumid-din, drugom izdanje, El-Matbe'atul-ezherijjetulmisrijjetu, 1316. h.

10. Gazali, Er-Reddu 'alel-batinijje, Tab'atu lejden 1916. god.

11. Gazali, El-Iktisadu fil-'itikadi, prvo izdanje, 1988. god., Darul-kutubililmijje, Bejrut.

12. Ibn Hišam, Es-Siretun-nebevijje, tahkik Mustafa Es-Saka ve Ibrahim el-Ebjari ve Abdulhafiz Šelebi, drugo mizdanje, Matbe'atul-babi elhalebi.

13. Ebu J'ala, El-Ahkamus-sultanijje, drugo izdanje, Matebe'tul-halebi, 1966. god.

14. Ibn Haldun, El-Mukaddime, treće izdanje, Daru ihjait-turasil-arabijji, Bejrut.

15. Ibn Hazm, El-Muhalla, Matbe'atul-imam, Kairo.

16. Ibn Hazm, El-Faslu fil-mileli ven-niheli, prvo izdanje, El-Matbe'atuledebijjeh, 1320. h.

17. Ibn Kesir, Tefsirul-Kur'anil-'azim, Daru ihjail-kutubil-arabijje.

18. Ibn Tejmijje, Minhadžus-sunneh, prvo izdanje, El-Matbe'atul-kubra elemirijje, 1321. h.

19. Ibn Tejmijje, Fetavi, Tab'atul-memleketil-arabijjetis-saudijje.

20. Ibn Tejmijje, El-Munteka min minhadžil-i'tidal fi nakdi kelami ihlirrefdi vel 'itizal, Vekaletut-tiba'ati vet-terdžemeti,Rijad, 1413. h.

21. Ibn S'ad, Et-Tabekatul-kubra, Bejrut, 1957. god.

22. Izuddin b. Abdusselam, Kava'idul-ahkam fi mesalihil- enam, Matbe'atul-istikame, Kairo, 1350. h.

23. Marginani, El-Hidaje, Matbe'atu Mustafa Muhammed, Egipat.

24. Maverdi, El-Ahkamus-sultanijje, prvo izdanje, Matbe'atu Mustafa elhalebi, Egipat, 1960. god.

25. Mevdudi, Nazarijetul-islamis-sijasijje, Metbe'atul-kitabi, Kairo, 1951. god.

26. Muhammed Abdullah el-Arabi, Nizamul-hukmi fil-islami, Darul-fikri, 1968. god. 
27. Muhammed Asad, Minhadžul-islami fil-hukmi, nekalehi ilel-arabijje Mensur Muhammed Madi, prvo izdanje, 1957. god., Darul-ilmi lilmelajin, Bejrut.

28. Razi, Mefatihul-gajb, prvo izdanje, El-Metbe'al-behijje, Egipat, 1938. god.

29. Remli, Nihajetul - muhtadž ila šerhil - minhadž, Mektebetu ve metbe'atu Mustafa el-halebi, Egipat, 1357. h.

30. Sujuti, Tarihul-hulefa, tahkik Muhammed Muhjuddin Abdulhamid, Matbe'atul-medeni, Kairo, treće izdanje, 1383. h.

31. Sulejman Tamavi, Omer b. El-Hattab ve usulu-s-sijaseti vel idaretil hadiseti, prvo izdanje, Darul-fikril-arabijji, 1969. god.

32. Tantavi, Ahbaru Omere, prvo izdanje, Darul-fikri, Damask, 1379. h.

33. Teftezani, El-Akaidun-nesefijje bišerhit-Teftezani, Tab'atu dari ihjailkutubil-arabijjeti, Egipat. 


\author{
Sulejman Topoljak, PhD \\ University of Bihac \\ Islamic Pedagogical Faculty \\ sulejman.topoljak@hotmail.com
}

\title{
CERTAIN ASPECTS OF THE ISLAMIC POLITICAL SYSTEM IN A VISION OF MODERN DEMOCRATIC THOUGHT
}

\section{Abstract}

Traditional legal texts of Islam have suggested that the part of Islam that will first disappear is the goverment, ie the political system, and the last thing that the Muslims will ignore will be salah. Contemporary Muslims have experienced exactly this indication, because they are living without their supreme secular - religious authority for almost an entire century. History clearly affirms that this prediction has been more understood and believed by nonmuslims more than the Muslims themselves, because they gave all of their potentials and strengths to realize it, so they succeeded, and at the same time the belief of the Muslims was not at their level, so allowed them to realize their greatest historical venture and dream that enabled them all of that they have and work for today. We deeply believe that the disappearance of the Islamic government and the non-implementation of the Islamic political system is the main cause of all the misery of today's Muslims, and until it is removed, the Muslims can not hope for anything positive oreven a brighter future. After the disappearance of the Caliphate there were sincere and real attempts to reestablish it and reactivate it, but unfortunately they did not give the desired results. After that, this desire and endeavor of the Muslims has slowly disappeared and eventually the non-Muslims through their satellites, installed at the most eminent Islamic universities, succeeded in convincing most Muslims and their quasi-scholars that there is no political system and politics in Islam, and that the believer can only be apolitical but not political. Unfortunately, this conviction is also transmitted to us in the Balkans, which is confirmed by the fact that there are no subjects that directly or indirectly have an affiliation with the Islamic political system or Islamic politics on any of our faculties.

Because of our such ignorant attitude towards a such important matter, I decided to write this study, whose goal is to briefly and with modern language explore the most important element of the Islamic political system - the institution of the rulers in Islam, in order to at least give a little contribute to 
its actualization, and perhaps stimulate and encourage somebody to start seriously thinking about it and research it, and to remind everyone who forgot or perhaps do not know that Islam is the whole system of life that involves both the principles and norms and the Islamic political system, and not just a religion as well as other know contemporary religion, as many of our contemporary secularists think and advise their students in Islamic faculties with us to study the foundations of secularism, not Islamic political system. In principle, it can be concluded that the Islamic political system rests on three elements: the institution of the ruler, the Shura institution and the institution of subjugation of the ruler and the Islamic ummah to the Shari'ah - the Islamic constitution and the law. Time, space and form of study do not allow us to look at the other two elements of the Islamic political system.

Keywords: Islam, Islamic political system, ruler, caliph, oath, power, sovereignty, people 


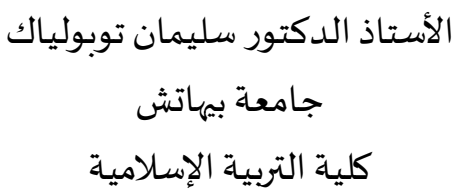

sulejman.topoljak@hotmail.com

بعض جو انب نظام الإسلام السياسي من منظور الفكر الديمقراطي المعاصر

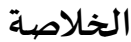

نصوص الإسلام القانونية التقليدية قد نبأت بأن أول ما يندثر من الإسلام هو

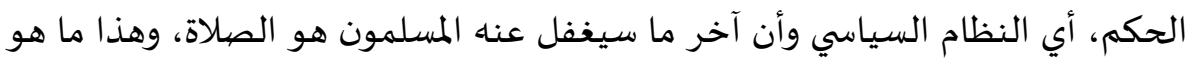

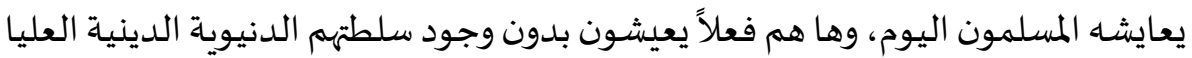

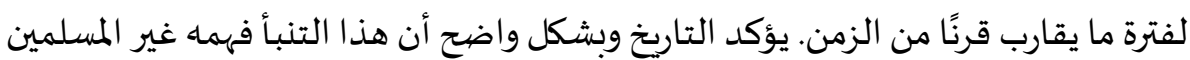

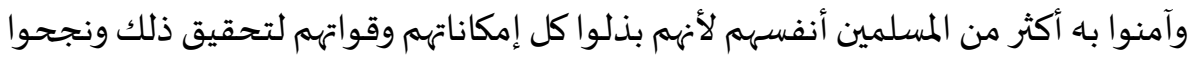

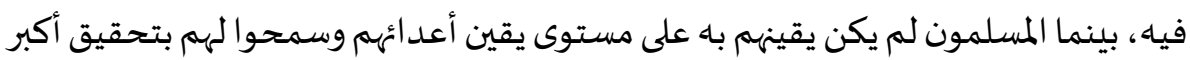

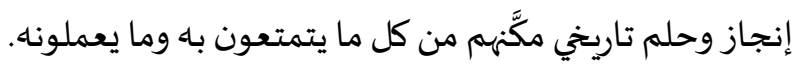

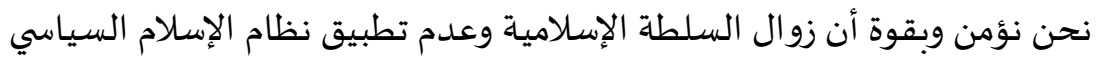

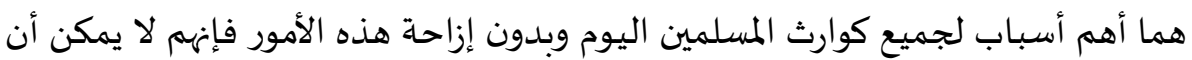

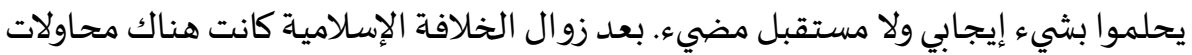

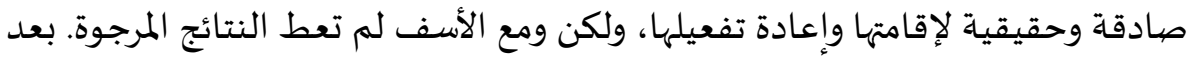

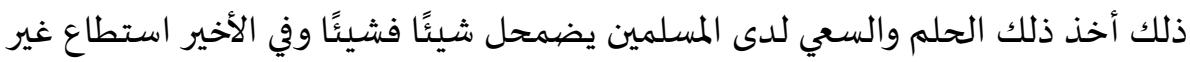
المسلمين عن طريق عملانهم في أرقى جامعات العالم الإسلامي أن يقنعوا أكثرية المسلمين

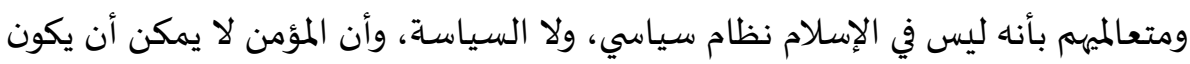

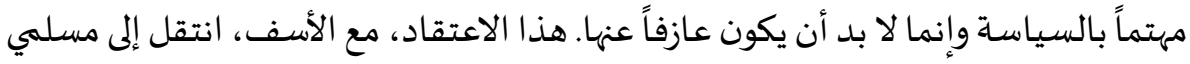

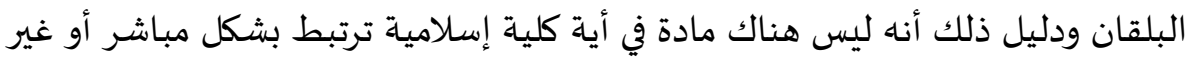

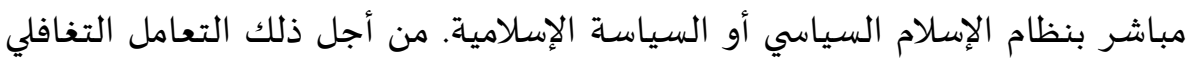

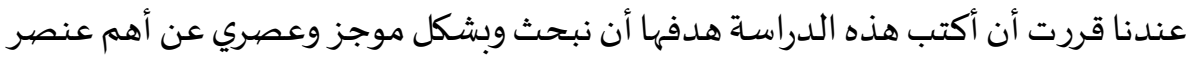

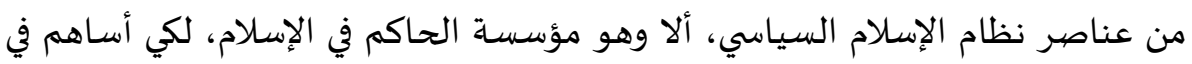

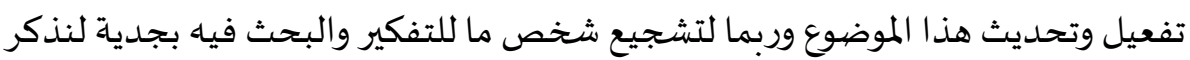


كل من نسوا أو جهلوا أن الإسلام نظام تكاملي للحياة يتضمن مبادئ نظام الإسلام السياسي

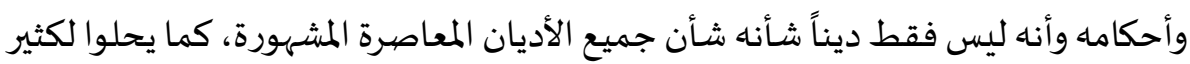

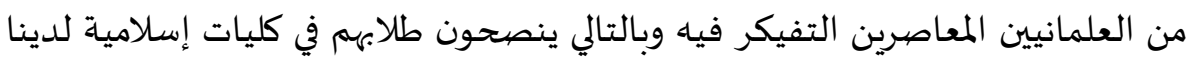
بدراسـة أسس العلمانية وليس نظام الإسلام السياسي. نستطيع وبشكل مبدئي القول إن نظام الإسلام السياسي يقوم على ثلاثة عناصر: الإسلام السياسي

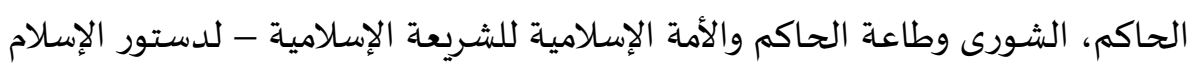

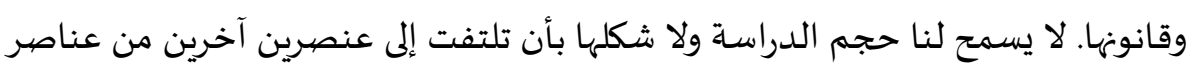
نظام الإسلام السياسي.

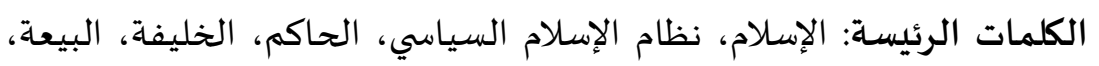

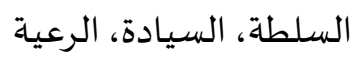

